\title{
Nanomaterials and hepatic disease: toxicokinetics, disease types, intrinsic mechanisms, liver susceptibility, and influencing factors
}

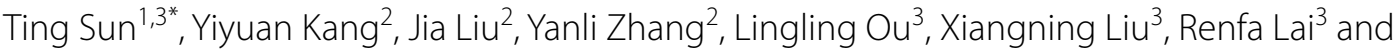
Longquan Shao ${ }^{2^{*}}$ (D)

\begin{abstract}
The widespread use of nanomaterials (NMs) has raised concerns that exposure to them may introduce potential risks to the human body and environment. The liver is the main target organ for NMs. Hepatotoxic effects caused by NMs have been observed in recent studies but have not been linked to liver disease, and the intrinsic mechanisms are poorly elucidated. Additionally, NMs exhibit varied toxicokinetics and induce enhanced toxic effects in susceptible livers; however, thus far, this issue has not been thoroughly reviewed. This review provides an overview of the toxicokinetics of NMs. We highlight the possibility that NMs induce hepatic diseases, including nonalcoholic steatohepatitis (NASH), fibrosis, liver cancer, and metabolic disorders, and explore the underlying intrinsic mechanisms. Additionally, NM toxicokinetics and the potential induced risks in the livers of susceptible individuals, including subjects with liver disease, obese individuals, aging individuals and individuals of both sexes, are summarized. To understand how NM type affect their toxicity, the influences of the physicochemical and morphological (PCM) properties of NMs on their toxicokinetics and toxicity are also explored. This review provides guidance for further toxicological studies on NMs and will be important for the further development of NMs for applications in various fields.
\end{abstract}

Keywords: Nanomaterials, Hepatic disease, Mechanisms, Susceptible individuals, Toxicokinetics

\section{Background}

With the development of nanotechnology, nanomaterials (NMs) are increasingly being used in various industrial, agricultural and commercial applications-e.g., as additives in food, sunscreens, cosmetics, pharmaceutical products, agricultural products and diesel fuel [1-3]. In healthcare and the life sciences, NMs also have different medical uses (e.g., as drug delivery systems, antibacterial

\footnotetext{
*Correspondence: sunting@jnu.edu.cn; shaolongquan@smu.edu.cn

${ }^{1}$ Foshan Stomatological Hospital, Foshan University, Foshan 528000, China

2 Stomatological Hospital, Southern Medical University,

Guangzhou 510280, China

Full list of author information is available at the end of the article
}

agents, magnetic resonance imaging (MRI) agents, and hyperthermia treatment media) and biotechnological applications (e.g., as biosensors) [4]. The widespread use of NMs has raised concerns that human exposure to NMs may introduce potential risks to the human body and environment. The NMs currently used in various fields cover a broad spectrum, ranging from liposomes, polymers, micelles, nanocrystals, and protein-based NMs to inorganic NMs. Generally, organic NMs are considered less toxic than inorganic NMs because they are not biopersistent and are more likely to be metabolized and cleared from the body [4]. Thus, the literature on nanotoxicity has focused mainly on the toxicity of inorganic NMs. 
The liver is the primary organ involved in the metabolism and detoxification of toxins and xenobiotics and is a major target organ for NMs. Consequently, liver impairments-e.g., oxidative stress, inflammatory stress, liver dysfunction, DNA damage, steatosis, fibrosis, and cell death-caused by NMs have been observed in numerous studies [5-8]. However, the hepatotoxic effects of NMs have not been linked to liver disease, and the intrinsic mechanisms have not been well demonstrated. Additionally, NMs exhibit varied toxicokinetics and induce enhanced toxic effects in susceptible livers; however, this issue has been ignored in recent toxicity studies. Therefore, this review discusses possible NMinduced liver diseases and the intrinsic mechanisms based on the current understanding of NM toxicokinetics and considers the contribution of potential susceptibility factors to provide guidelines for the biosafety of NMs. To understand how NM type affect their toxicity, the influences of the PCM properties of NMs on their toxicokinetics and toxicity are also explored.

\section{Characteristics of the liver}

The liver is a solid organ comprising mainly hepatocytes and less abundant cells. The less abundant cells include monocytes, Kupffer cells (KCs), liver sinusoidal endothelial cells (LSECs), hepatic stellate cells (HSCs), biliary epithelial cells (e.g., BECs and cholangiocytes), resident immune cells (i.e., natural killer cells, dendritic cells and lymphocytes), hepatic progenitor cells (HPCs), and circulating blood cells and immune cells in transit through the liver. KCs, the major components of the mononuclear phagocyte system (MPS), the largest population of resident macrophages in the body, account for $15 \%$ of the total liver cells and perform a janitorial function, protecting hepatocytes through the removal of xenobiotics and cellular debris via cellular phagocytosis and phagolysosomal digestion [9]. The hepatic barrier comprises LSECs and the extracellular matrix (ECM). The ECM is a network of collagen, proteins, and elastic fibers that provide the structural integrity to the tissue. LSECs are highly specialized endothelial cells, characteristic of a discontinuous architecture, meaning that fusion of the luminal and abluminal plasma membrane occurs at sites other than cell junctions, in areas called 'fenestrae. HSCs are involved in forming basement membrane-like structures via the secretion of laminin, proteoglycans, and type IV collagens. Hepatocytes, which exist under the LSEC layer, constitute $70 \%-80 \%$ of all liver cells and are responsible for maintaining liver functions.

A schematic diagram of the liver structure and hepatic cells is shown in Fig. 1.

\section{Characteristics of NMs}

Normally used inorganic NMs can generally be classified as metal or metal oxide $\mathrm{NMs}$ (e.g., $\mathrm{Au}-, \mathrm{Ag}_{-}, \mathrm{ZnO}-, \mathrm{TiO}_{2^{-}}$, and $\mathrm{CuO}-\mathrm{NPs}$ ) or non-metal NMs (e.g., carbon nanotubes (CNTs), black phosphorus (BP) NMs, and Si-NPs). NMs can also be classified by their structure and shape into quantum dots (QDs), nanotubes (NTs), nanowires, nanorods (NRs) and nanobelts.

\section{Metal NMs}

ZnO-NPs are among the most commonly used NMs in industrial, biomedical and dental applications. For example, $\mathrm{ZnO}$-NPs are commonly used as additives in electronic components because of their semiconductor properties and are considered important physical UV filters in sunscreens due to their very high UV-protection capacity. ZnO-NPs also exhibit fair antimicrobial, antifungal and anti-tumor cell properties because of their high surface-to-volume ratio and ability to destroy the cell integrity, release $\mathrm{Zn}^{2+}$ ions and stimulate reactive oxygen species (ROS) formation [10]. However, studies have suggested the toxic effects of both solid $\mathrm{ZnO}-\mathrm{NPs}$ and dissolved $\mathrm{Zn}^{2+}$ on normal cells [11].

Recently, $\mathrm{TiO}_{2}-\mathrm{NPs}$ have been widely applied in industrial and consumer products-e.g., cosmetics, paints, glass, electronic devices, and food additives-because of their high catalytic activity, high stability and resistance to corrosion. However, $\mathrm{TiO}_{2}$ is considered a human carcinogen by inhalation (Category 1B) by the Risk Assessment Committee of the European Chemicals Agency (ECHA), and $\mathrm{TiO}_{2}$-NP toxicity is closely related to the release of $\mathrm{Ti}^{2+}$ [12]. Furthermore, the French Agency for Food, Environmental and Occupational Health and Safety (ANSES) banned the application of $\mathrm{TiO}_{2}$ as food additives (E171) because of its genotoxic potential [13].

Because of their unique physiochemical properties, copper $(\mathrm{Cu})$-based NPs-e.g., Cu-NPs, CuO-NPs and $\mathrm{Cu}_{2} \mathrm{CO}_{3}(\mathrm{OH})_{2}-\mathrm{NPs}$-are widely applied in technical fields, such as in wood protection, electronics, catalysts, antimicrobial supplements in poultry feed and intrauterine contraceptive devices, and are taken up by humans via inhalational and oral routes (hand-to-mouth transfer during installation) [14]. Under overload conditions, copper is potentially toxic because of its redox activity and high affinity towards thiols and proteins or enzymes.

Ag-NPs are widely used in food additives, food packaging, textiles, electronics, cosmetics, household appliances, medical devices, room sprays and water disinfectants because of their attractive antibacterial and plasmonic properties. However, no silver-based nanocarriers have been approved by the FDA for the systemic delivery of other bioactive agents [15]. The surface of Ag-NPs can be oxidized by $\mathrm{O}_{2}$ and other molecules in 


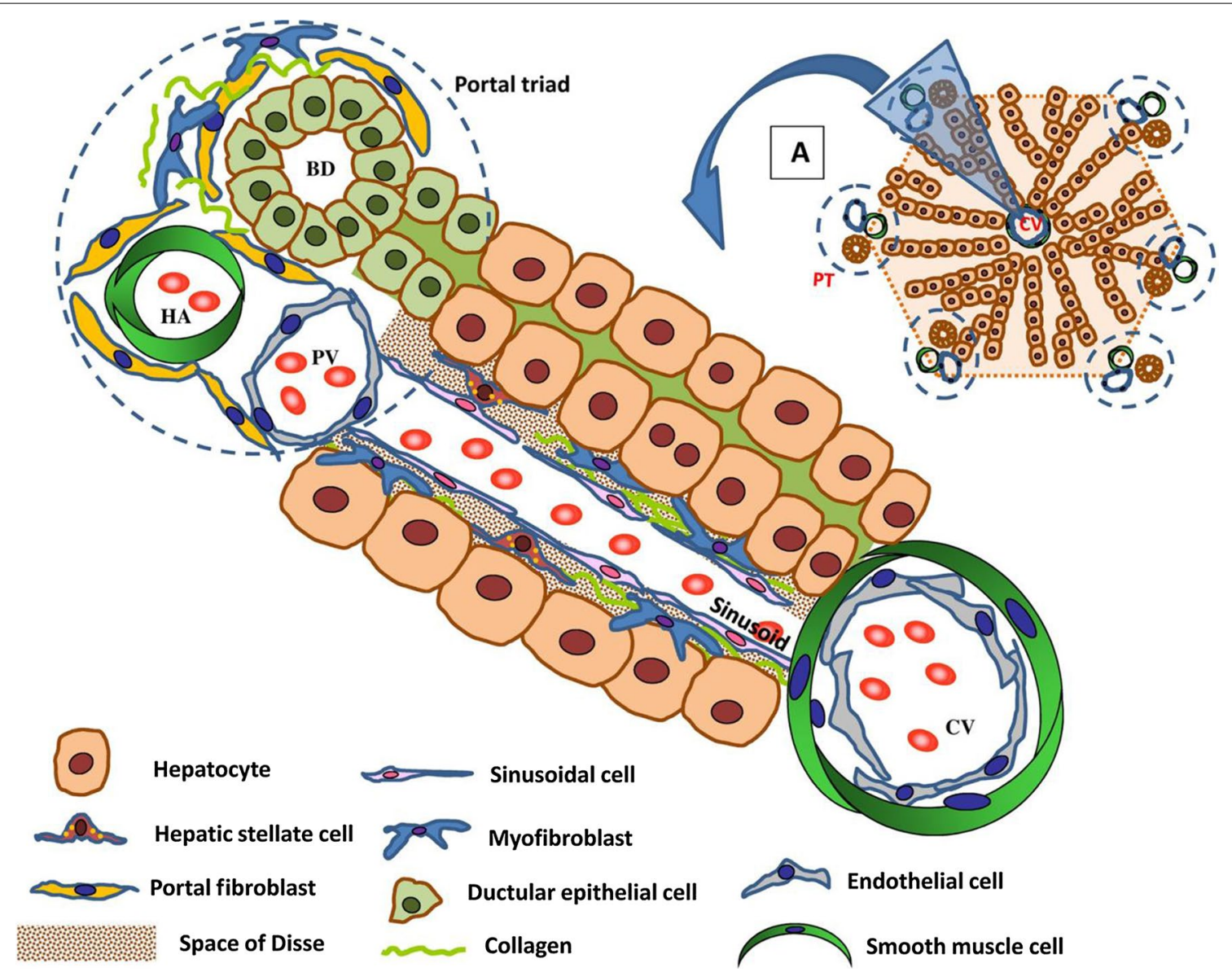

Fig. 1 Schematic of the liver structure and hepatic cells. The liver comprises lobules, representing hepatic functional units (panel A). Each lobule is intersected by a central vein (CV), from which hepatocyte cords radiate towards portal triads (PTs) containing three different structures: bile ducts (BD), a hepatic artery (HA) and a portal vein (PV). Hepatocyte cords are separated by sinusoids, which are blood vessels lined by specialized fenestrated endothelial cells (liver sinusoidal cells). Hepatic stellate cells (HSCs) are located in the space of Disse, and portal fibroblasts (PFs) are located in the portal triad areas. Ductal epithelial cells line the bile ducts. Reprinted with permission from [202]. Copyright 2017 Wiley

the environment and biological systems, resulting in the release of $\mathrm{Ag}^{+}$, a known toxic ion. Ag-NPs can lead to physical damage to the cell membrane and ROS generation, resulting in dysfunction of key cellular components following the release of Ag ions [16].

\section{Non-metal NMs}

Carbon NMs include 0D fullerene, carbon dots, nanodiamonds, graphene QDs, 1D CNTs, 2D graphene and its derivatives, and graphitic carbon nitride. Carbon NMs are widely used in biomedicine, energy and sensing because of their excellent electronic and optical properties, good biocompatibility, fair surface function and high reactivity. However, because of their light weight and small size, they are prone to aerosolization, leading to inhalation and potential toxic effects [17].
Si-NPs are widely applied in industry as food additives, beverage ingredients, drug and vitamin excipients, and cosmetic product additives. Mesoporous Si-NPs have striking characteristics for application as drug carriers because they can adsorb and release drug molecules. However, Si-NPs can absorb toxic agents on the cell surface, increasing their toxicity potential [18].

\section{Toxicokinetics of NMs}

Recently, the toxicokinetics of NMs has become an important part of nanotoxicological studies. In this section, the toxicokinetics of NMs is discussed.

\section{Administration routes and distribution of NMs}

NMs enter the liver through the blood circulation. NMs enter the blood circulation directly or indirectly by passing through normal physiological barriers, such as the 
air-blood barrier (ABB) and gastrointestinal tract (GIT) barrier. The liver uptake ratio of NPs (from high to low) administered via different routes is as follows: intravascular, inhalation, and oral administration.

After entering the blood circulation, intravenously injected NMs are primarily captured by the MPS. As a filtration organ containing cells in the MPS with a fenestrated vasculature and high populations of committed phagocytes, the liver rapidly captures a large amount of intravascularly administered NMs after administration. Approximately, 30\%-99\% of administered NMs from the bloodstream are captured by the liver [4]. The liver concentration of intravenously administered NMs is very high even at low injection doses. For example, a quantitative toxicokinetics study showed that $\mathrm{TiO}_{2}-\mathrm{NPs}$ $(70 \mathrm{~nm})$ were accumulated mainly in the liver $(95.5 \%$ of the injected dose after $4 \mathrm{~h}$ and $88.9 \%$ of the injected dose after $28 \mathrm{~d})$ post intravenous administration $(40.13 \mu \mathrm{g} / \mathrm{kg}$ b.w. for the 4-h group and $127.44 \mu \mathrm{g} / \mathrm{kg}$ b.w. for the $28-\mathrm{d}$ group) [19].

Most respiratory-administered NMs deposited in the lung are taken up by macrophages and ultimately dissolve. Only a small amount of respiratory-administered NMs can pass through the $\mathrm{ABB}$ and translocate to the blood and liver, even at high doses. In vivo studies reported that the translocation rate of respiratory-administered $\mathrm{NMs}$ (i.e., $\mathrm{TiO}_{2^{-}}, \mathrm{Ag}-, \mathrm{CeO}_{2^{-}}$and $\mathrm{Au}-\mathrm{NPs}$ ) across the $\mathrm{ABB}$ was $0.1 \%-5 \%$ of the initial peripheral lung dose (IPLD) $[20,21]$ and $0.1 \%-2 \%$ of the administration dose [22-25]. Furthermore, the translocation rate of these NMs to the liver was approximately $0.001 \%-0.5 \%$ of the initial lung dose (ILD) $[20,21,26]$ and $0.0023 \%-0.02 \%$ of the administration dose [22-25, 27].

The kinetics of orally administered NMs are more similar to the kinetics of respiratory-administered NMs than to the kinetics of intravenously injected NMs. A very small amount of orally administered NMs can pass through the GIT and translocate to the blood and liver. For example, studies have shown that Au-NPs (1.4$200 \mathrm{~nm}$ ) accumulated predominantly in the liver post intravenous administration, while liver retention was tenfold higher after intravenous administration than after oral administration $[28,29]$. The translocation fraction of orally administered $\mathrm{NMs}\left(\mathrm{TiO}_{2}-, \mathrm{Ag}-\right.$, and $\left.\mathrm{Au}-\mathrm{NPs}\right)$ across the GIT barrier was $0.00 \%-0.88 \%$ of the administration dose [29-31].

\section{Metabolism and elimination of NMs}

NMs escaping the MPS may be taken up by LSECs or pass through the LSEC fenestrae, filter out into the perisinusoidal space and be taken up by hepatocytes and HSCs. NMs are cleared from the body by the MPS, and renal and hepatobiliary systems.
The intracellular trafficking of NMs is summarized as follows. Following uptake, NMs are typically entrapped in vesicular structures, such as endosomes. After endosomal maturation, most endosomal components are delivered to and then degraded in lysosomes. On some occasions, NMs can escape from endosomes and subsequently target intracellular organelles. NMs can be degraded in lysosomes via enzymatic degradation or nonenzymatic degradation. Many xenobiotic metabolizing enzymes with overlapping substrates exist in the lysosomes of liver cells and are usually classified as either phase I enzymes (e.g., CYP450 and flavincontaining monooxygenases) with the main function of oxidizing xenobiotics or phase II enzymes (e.g., glutathione S-transferases, glucuronyl transferases, and sulfotransferases) with the main function of conjugating xenobiotics. Additionally, minor phase I enzymes include epoxide hydrolases, prostaglandin synthetase, dehydrogenases, hydrolases, and proteases. Metal NMs and their oxides may be dissolved to metal ions, which bind to acid radicals, forming metal salt products. For example, Ag-NPs are dissolved in L-929 fibroblast cells and reform insoluble silver species, such as $\mathrm{AgCl}$ or AgS [32]. Nonmetallic NMs and their oxides may be degraded into acids. For example, $\mathrm{SiO}_{2}$ and $\mathrm{Si}-\mathrm{NPs}$ are degraded into silicic acid- $\mathrm{Si}(\mathrm{OH})_{4}$ and $\mathrm{Si}\left(\mathrm{OH}_{4}\right)$, respectively, via successive hydration, hydrolysis, and ion exchange steps [33]. BP-NPs can be degraded into phosphoric acids, such as $\mathrm{H}_{3} \mathrm{PO}_{4}$ [34]. $\mathrm{NM}$ degradation products released from lysosomes can target intracellular organelles. Finally, NM degradation products are excreted from cells into the extracellular space via exocytosis in the form of membrane-wrapped vesicles, usually mediated by lysosomes.

A schematic diagram of the hepatic filtration system for NMs and intracellular trafficking of NMs is shown in Fig. 2. The toxicokinetics of representative NMs is summarized in Table 1.

\section{NMs exhibit potential risks for liver disease}

The liver is the main target organ of NMs, and liver impairments caused by NMs have been observed in numerous studies. For example, liver impairments such as oxidative stress, inflammatory stress, liver dysfunction, steatosis, fibrosis, DNA damage, and cell death caused by NMs have been widely reported [5-8]. However, the hepatotoxic effects of NMs have not been linked to liver disease, and the toxicity mechanism has not been well demonstrated. This section discusses potential risks for liver diseases induced by various NMs and examines their toxicity mechanisms. 


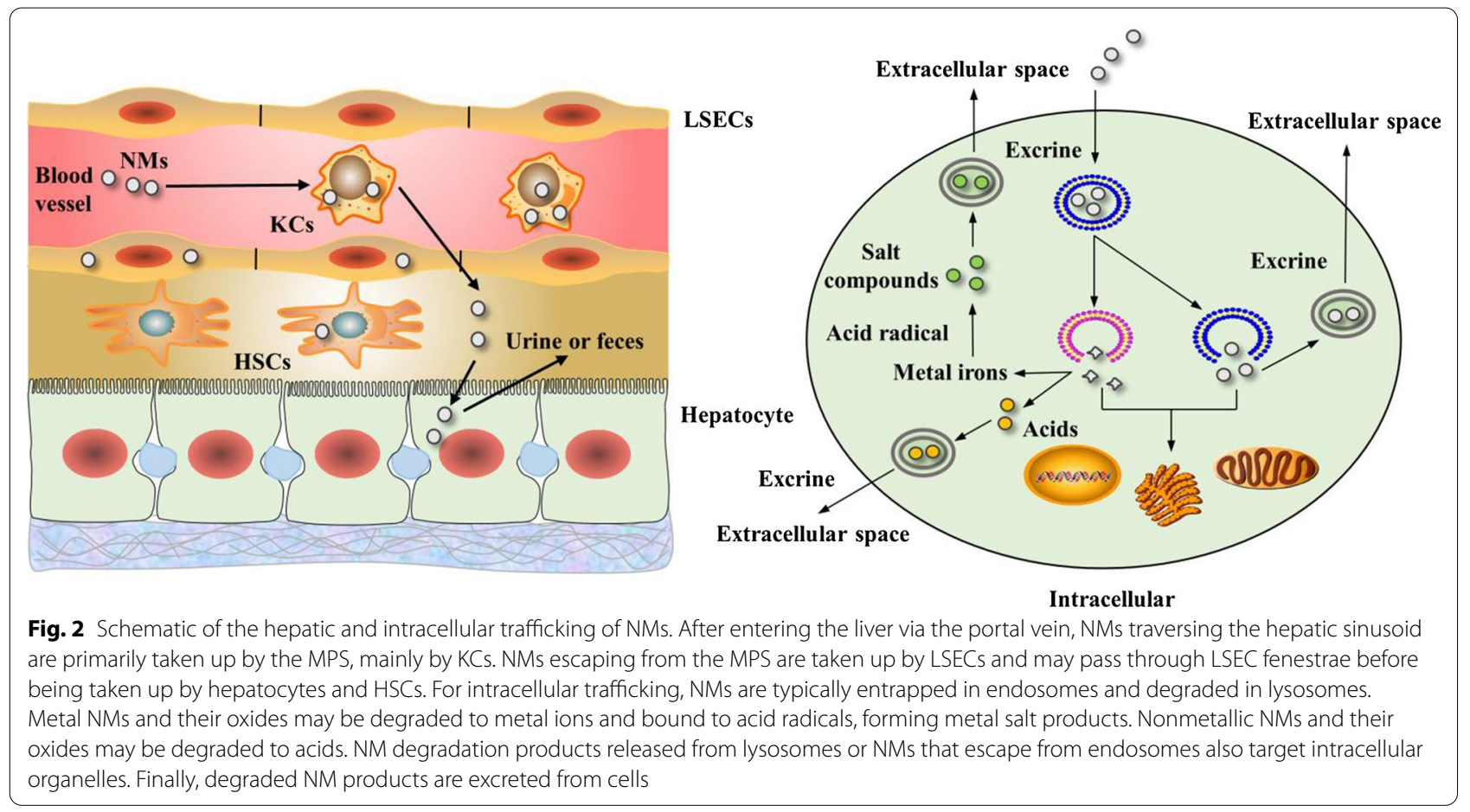

\section{Nonalcoholic steatohepatitis (NASH)}

Nonalcoholic fatty liver disease (NAFLD) is a chronic liver disease that encompasses a wide spectrum of liver diseases that develop progressively from simple steatosis to NASH, fibrosis, and even cirrhosis [35]. Compared with steatosis, NASH is considered a more severe process in which an inflammatory response, liver cell damage, and pericellular fibrosis are involved, and NASH may develop into cirrhosis.

Current studies have shown that several NMs (i.e., CuNPs and $\mathrm{ZnO}$-NPs) induce hepatic steatosis, oxidative stress, and cytochrome P450 (CYP450) dysregulation [7, 36, 37]. Further studies have shown that NMs (i.e., ZnO-, $\mathrm{CeO}_{2^{-}}, \mathrm{Au}-, \mathrm{CuO}-$ and $\mathrm{SiO}_{2}-\mathrm{NPs}$ ) lead to increased lipid synthesis, particularly increased FFA levels [7, 38-41]. Researchers generally presume that NASH is initiated by the overaccumulation of free fatty acids (FFAs) in the liver, attributed to impaired postreceptor signaling induced by insulin resistance (IR). Excessive FFAs lead to lipotoxicity to hepatocytes by inducing ER stress, oxidant stress and inflammasome activation, meanwhile are converted to triglycerides and stored in lipid droplets. IR is initiated by inflammation and cytokine release driven by the NF- $\mathrm{KB}$ and MAPK pathways (including ERK, p38 MAPK, and JNK) that lead to the phosphorylation of insulin receptors (IRSs) [42]. Dephosphorylation of IRS1 on serine/threonine residues further initiates the recruitment and activation of PI3K, which phosphorylates serine/threonine moieties of AKT, leading to IR [43].
Importantly, $\mathrm{NMs}$ (such as $\mathrm{SiO}_{2^{-}}, \mathrm{TiO}_{2^{-}}$, and $\mathrm{ZnO-NPs}$ ) induces IR via IRS1 phosphorylation and phosphorylation inhibition of the serine residues of AKT, which is activated by ROS-activated inflammation mediated by the MAPK and NF- $\mathrm{kB}$ pathways [44-48]. Based on the above evidence, we postulate that NM exposure may induce NASH by triggering hepatic IR, which is activated by ROS-activated inflammation mediated by the MAPK and NF-kB pathways.

As discussed above, KCs play an important role in NMinduced liver injury because NMs are primarily captured by KCs. The uptake of various NMs (i.e., carbon black, graphene NPs, SIPONs, $\mathrm{Cu}-, \mathrm{SiO}_{2^{-}}$, and $\mathrm{TiO}_{2}-\mathrm{NPs}$ ) leads to macrophage activation and the release of cytokine (e.g., TNF- $\alpha, \mathrm{L}-1 \beta$ and IL-18) by activating Toll-like receptors (TLRs), such as TLR 2, 4, and 9, followed by activation of NF-kB, MAPK and JNK signaling [49-54]. TLRs, particularly TLR 2, 4, and 9, regulates inflammation and insulin resistance [55]. Thus, we assumed that $\mathrm{NM}$-activated KCs contribute to IR and lipotoxicity in hepatocytes via the release of cytokines and chemokines. Furthermore, persistent stimuli, such as cytokines, lipid peroxides and molecules, from activated $\mathrm{KCs}$ and injured hepatocytes induce HSC activation, leading to fibrogenesis or even cirrhosis.

Thus far, few studies have proven that NMs induce NASH because most of the available toxicological studies on NMs have adopted limited exposure times, most commonly ranging from $1 \mathrm{~d}$ to 1 or 2 months, mainly 


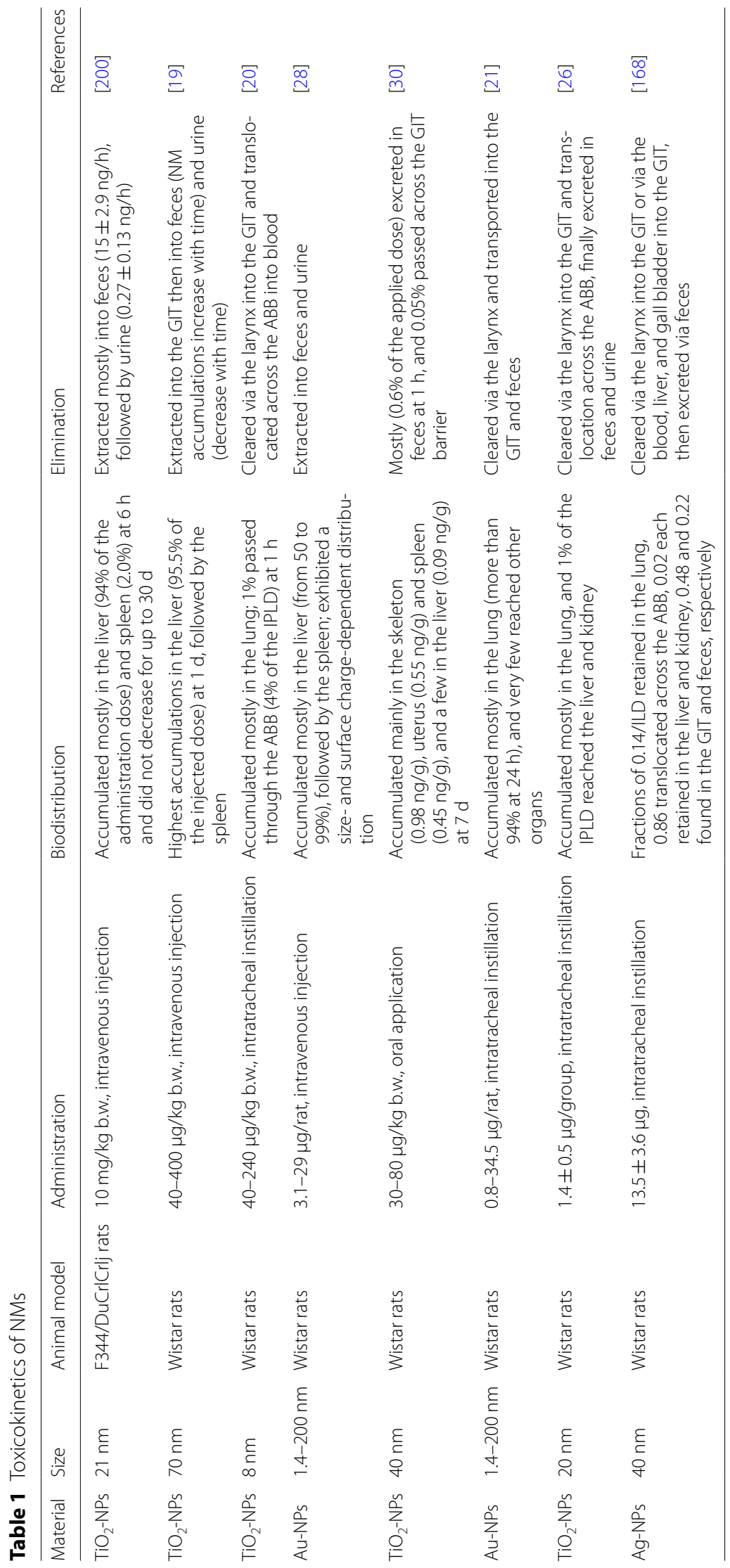


representing acute (up to $14 \mathrm{~d}$ ), subacute (up to $28 \mathrm{~d}$ ) and subchronic (up to $90 \mathrm{~d}$ ) exposure. A study with an exposure time of up to 1 year proved that intratracheally administered MWCNTs trigger a NASH-like phenotype in mouse livers, characterized by inflammation, steatosis, and fibrosis [56]. Thus, chronic (up to 4 months) hepatotoxicological studies of NMs remain a challenge.

A schematic of the main mechanisms of NM-induced $\mathrm{NASH}$ is presented in Fig. 3. Representative studies revealing the contributions of NMs to NASH are summarized in Table 2.

\section{Fibrosis}

Exposure to several NMs (from $28 \mathrm{~d}$ to 9 months) has been shown to induce hepatic fibrosis without inducing hepatic steatosis, such as $\mathrm{TiO}_{2}$-NPs [57-59], $\mathrm{Cu}-\mathrm{NPs}$ [60], $\mathrm{SiO}_{2}$-NPs [6], Si-NPs [61, 62], Ag-NPs [63], NiONPs [64], and CNTs [56]. Fibrogenesis occurs because of the transformation of HSCs into fibroblasts, which produce ECM faster than it is degraded. During hepatic fibrosis development, the composition of the hepatic
ECM transitions from collagen IV and laminin to collagen I and III. Innate immune signaling, particularly that mediated by cytokines and TLRs, contributes to HSC activation.

TGF- $\beta$, well acknowledged as the most potent fibrogenic cytokine, excreted by KCs and HSCs, is initially induced by the adaptive immune response (including IL-4, IL-5, IL-13 and IL-17 release). Activation of TGF- $\beta$ / small mothers against decapentaplegic (SMAD) signaling plays an important role in HSC activation. Activation of TGF- $\beta$ mediates noncanonical SMAD-independent pathways-e.g., Rho/GTPase, PI3K/AKT, mTOR, and MAPK signaling pathways-which also contribute to HSC activation [65]. Current in vivo studies have shown that $\mathrm{NMs}-$ i.e., $\mathrm{Cu}-$-, $\mathrm{TiO}_{2}-$, and $\mathrm{NiO}-\mathrm{NPs}-$ induce hepatic fibrosis via the activation of TGF- $\beta / S M A D$-dependent and TGF- $\beta /$ SMAD-independent (i.e., MAPK/WNT, AKT/FOXO3) signaling [58, 60, 64, 66-68]. Thus, based on the evidence above, we postulate that NMs induce HSC activation by stimulating TGF- $\beta$ /SMAD-dependent and -independent signaling, leading to liver fibrosis.

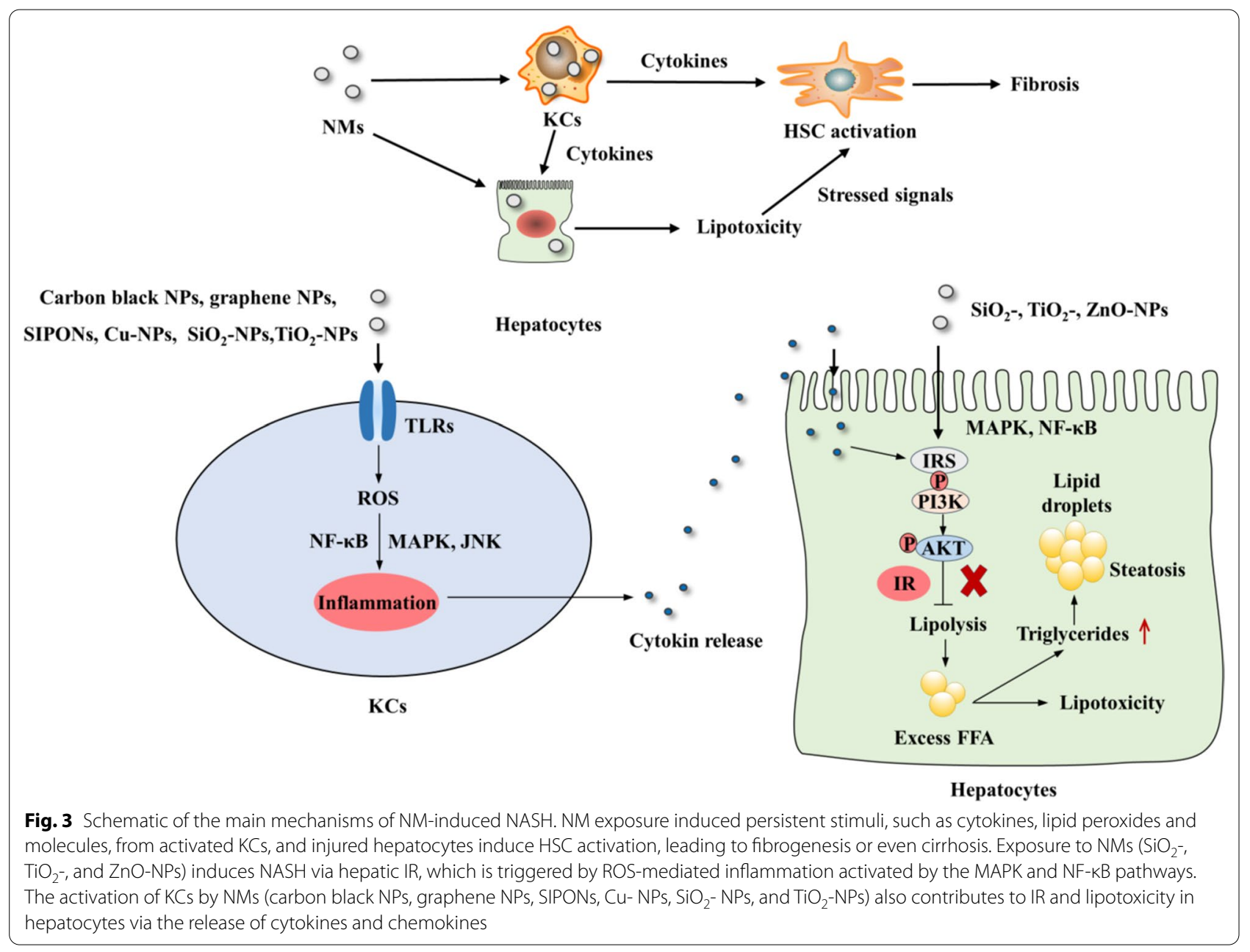


Table 2 NM-induced injuries that contribute to NASH

\begin{tabular}{|c|c|c|c|c|c|}
\hline NM & Size & Cells/animals & Dose and exposure time & Effects & References \\
\hline ZnO-NPs & $30 \mathrm{~nm}$ & Hens (Jinghong1 strain) & $\begin{array}{l}10 \mathrm{mg} / \mathrm{kg} \text { b.w., oral admin- } \\
\text { istration, } 4 \text { and } 24 \mathrm{~W}\end{array}$ & $\begin{array}{l}\text { Caused plasma metabo- } \\
\text { lomic perturbations } \\
\text { correlated with hepatic } \\
\text { steatosis }\end{array}$ & [7] \\
\hline Cu-NPs & $23.5 \mathrm{~nm}$ & ICR mice & $\begin{array}{l}341-1080 \mathrm{mg} / \mathrm{kg} \text { b.w., oral } \\
\text { administration, } 48 \mathrm{~h}\end{array}$ & Induced hepatic steatosis & [37] \\
\hline Au-NPs & $20 \mathrm{~nm}$ & Wistar rats & $\begin{array}{l}0.01 \mathrm{mg} / \mathrm{kg} \text { b.w., intrave- } \\
\text { nous injection, } 2 \text { months }\end{array}$ & $\begin{array}{l}\text { Induced alterations in gene } \\
\text { expression related to lipid } \\
\text { metabolism in the liver }\end{array}$ & [38] \\
\hline $\mathrm{CeO}_{2}-\mathrm{NPs}$ & $8 \mathrm{~nm}$ & HepG2 cells & $6.25-200 \mu \mathrm{g} / \mathrm{mL}, 24 \mathrm{~h}$ & $\begin{array}{l}\text { Induced oxidative stress } \\
\text { and increased the } \\
\text { content of many lipids, } \\
\text { particularly FFAs }\end{array}$ & [40] \\
\hline $\mathrm{CeO}_{2}-\mathrm{SiO}_{2}-, \mathrm{TiO}_{2}-\mathrm{CuO}-\mathrm{NPs}$ & 5 to $>500 \mathrm{~nm}$ & HepG2 cells & $\begin{array}{l}3 \mu \mathrm{g} / \mathrm{mL} \text { for } \mathrm{CuO}, 30 \mu \mathrm{g} / \mathrm{mL} \\
\text { for } \mathrm{CeO}_{2} \text { and } \mathrm{SiO}_{2} \text {, and } \\
100 \mu \mathrm{g} / \mathrm{mL} \text { for } \mathrm{CeO}_{2} ; 72 \mathrm{~h}\end{array}$ & $\begin{array}{l}\text { Triggered oxidative stress } \\
\text { and increased lipid con- } \\
\text { centrations }\end{array}$ & [39] \\
\hline $\begin{array}{l}\text { Au nanospheres and } \\
\text { nanostars }\end{array}$ & $40 \mathrm{~nm}$ & Wistar rats & $\begin{array}{l}1.33 \times 10^{11} / \mathrm{kg} \text { b.w., intrave- } \\
\text { nous administration, } 24 \mathrm{~h}\end{array}$ & $\begin{array}{l}\text { Triggered oxidative stress } \\
\text { and increased FFA levels }\end{array}$ & [41] \\
\hline MWCNTS & $\begin{array}{l}\text { Diameter: } \\
\quad 12.5 \pm 2.5 \mathrm{~nm} \text {, length: } \\
13.0 \pm 1.5 \mathrm{~mm}\end{array}$ & C57BL/6 J mice & $\begin{array}{l}0.1 \mathrm{mg} / \text { mice, intratracheal } \\
\text { administration, } 1 \text { year }\end{array}$ & $\begin{array}{l}\text { Induced inflammation, } \\
\text { steatosis, and fibrosis in } \\
\text { the liver }\end{array}$ & [56] \\
\hline
\end{tabular}

Activated HSCs express TLRs, including TLR2, TLR3, TLR4, TLR7 and TLR9 [69]. In quiescent HSCs, TLR4 activation upregulates chemokine secretion and the chemotaxis of KCs, as well as downregulates the expression of the TGF- $\beta$ pseudoreceptor BAMBI to sensitize HSCs to TGF- $\beta$-induced activation through a pathway dependent on myeloid differentiation primary response protein 88 (MYD88) and NF-kB [69]. In vitro studies showed that NMs-i.e., amorphous $\mathrm{Si}-\mathrm{NPs}$ and $\mathrm{Cu}$ NPs-induce inflammation via activation of the NLRP3 inflammasome and TLR4/MYD88/NF- $\mathrm{B}$ signaling pathway in macrophages and HUVECs [70, 71]. An in vivo study further proved that mesoporous $\mathrm{Si}-\mathrm{NPs}$ induce liver fibrosis via the TLR4/MYD88/NF- $\mathrm{B}$ signaling pathway [62]. Thus, we postulate that NMs induce HSC activation by activating TLR4/MYD88/NF- $\mathrm{kB}$ signaling.

As epigenetic signals, profibrogenic miR-21, miR-221/22, and miR-27 can activate HSCs [69]. In vivo and in vitro studies showed that NMs-i.e., graphene QDs and Ni-NPs-induce miR-21 regulation in immune cells and liver cells [72, 73]. Additionally, miR-21 is involved in Ni-NP-induced matrix metallopeptidase (MMP) production (including MMP-2 and MMP-9) [72]. MMP-2 and MMP-9 correlate with the severity of inflammation in NASH [74]. Further study shows exposure to Ni-NPs induces miR-21 upregulation, which promotes pulmonary fibrosis, characteristic of TGF- $\beta 1$ and SMAD2 phosphorylation, and increased COLI and III [75]. Thus, we postulate that NMs induce HSC activation by upregulating miR-21 expression.
Molecules such as TGF- $\beta$, Th2 cytokines (IL-4 or IL-13), and STAT6/STAT3 induce the polarization of M2 macrophages, which are essential for fibrosis. NMs (i.e., SPIONs and MWNTs) exposure to macrophages induce the M1-M2 polarization of macrophages driven by elevated Th2 cytokines (IL-4 and IL-13) [76, 77]. Activation of STAT3 observed in mesoporous Si-NPs induce liver fibrosis [62], and $\mathrm{Cu}-\mathrm{NPs}$ induce ROS generation, inflammation and CYP450 decrease in the liver [36]. In addition to the finding that NM exposure induces TGF- $\beta$ activation, we postulate that NMs induce HSC activation by triggering the M1-M2 polarization of $\mathrm{KCs}$ via activating IL-4, IL-13, TGF- $\beta$ and STAT3.

A schematic of the progression and main mechanisms of NM-induced hepatic fibrosis is shown in Fig. 4. Representative studies describing the contributions of NMs to liver fibrosis are summarized in Table 3.

\section{Liver cancer}

$\mathrm{HCC}$ is the most common liver cancer, accounting for $90 \%$ of all hepatic malignancies [78]. The biological mechanisms involved in the progression of HCC include the epithelial-to-mesenchymal transition (EMT), tumorstromal interactions, the tumor microenvironment, dysregulation of microRNAs and some well-known signaling pathways.

Currently, a few chronic exposure studies have confirmed that NMs (e.g., Si- NPs, ZnO-NPs, $\mathrm{TiO}_{2}-\mathrm{NPs}$, Ag- NPs, lipid NPs, carbon NPs, and SWCNTs) potentially trigger tumorigenesis or carcinogenesis [79-84]. 


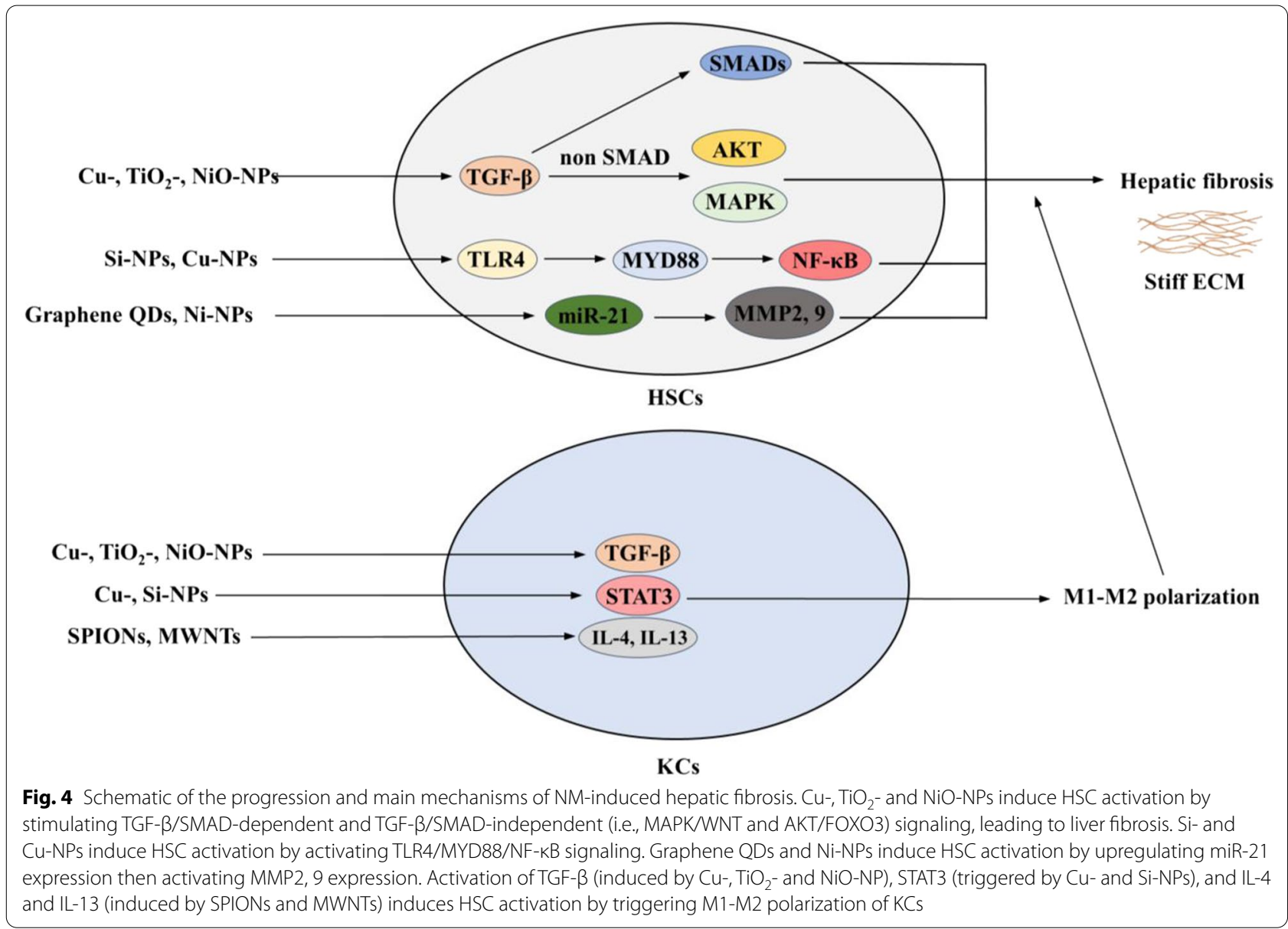

Additionally, the induction of EMT occurrence by NMs ( $\mathrm{NiO}$ and $\mathrm{TiO}_{2}$-NPs) has been recognized [64, 85]. During the EMT process, epithelial cells lose their cell adhesive properties to each other and a basement membrane and become migratory in nature. The EMT allows cancer cells to avoid death and is a general immune defense. As an external EMT-inducing factor acquired from the microenvironment, TGF- $\beta$ plays an important role in signals mediating EMT progression, suppressing epithelial differentiation. The TGF- $\beta$ / WNT, TGF- $\beta$ /SMAD, TGF- $\beta$ /MAPK signaling pathways participate in EMT progression [86]. More importantly, a recent study using both in vivo and in vitro components proved that NiO-NPs induce hepatic fibrosis and EMT occurrence through TGF- $\beta 1$-mediated SMAD pathway activation $[64,85]$. Additionally, $\mathrm{TiO}_{2}$ and NiO-NP-induced TGF- $\beta /$ SMAD, TGF- $\beta / \mathrm{WNT}$ and TGF- $\beta / \mathrm{PI} 3 \mathrm{~K} / \mathrm{AKT} / \mathrm{mTOR}$ signaling activation has been reported [58, 60, 64, 66-68]. Therefore, we assume that NMs may induce EMT occurrence by activating TGF$\beta$-mediated WNT, SMAD and MAPK signaling.
Gap junctions are considered an important communication between tumor cells and stromal cells. Loss of Gap junctional intercellular communication (GJIC) and reduced connexin $(\mathrm{Cx})$ expression exacerbate cancer EMT and metastasis [87]. An in vivo study showed that $\mathrm{SiO}_{2}$-NP exposure induces GJIC dysregulation involved in $\mathrm{Cx} 43$ phosphorylation [88]. $\mathrm{Cx} 43$ can be activated by MAPK activation [89]. Importantly, $\mathrm{SiO}_{2}$ - NP exposureinduced Cx43 phosphorylation is mediated by ERK/ MAPK signaling [88]. Therefore, we assume NMs may exacerbate EMT through induce GIC dysregulation involved in Cx43 phosphorylation via activating ERK/ MAPK signaling.

MiR-21, an important oncogenic mir-RNA, is involved in enhancing EMT, cell proliferation, invasion, migration, apoptosis, and cell elongation in HCC cells by promoting TGF- $\beta /$ MAPK, TGF- $\beta /$ SMAD and JNK pathways [90]. Activation of miR-21 also increases the expression of MMP-2 and MMP-9, known cancer markers involved in invasion, metastasis and angiogenesis of cancer. An in vitro study showed that graphene QDs induce miR-21 
Table 3 NM-induced injuries that contribute to fibrosis

\begin{tabular}{|c|c|c|c|c|c|}
\hline NMs & Size & Cells/animals & Dose and exposure time & Effects & References \\
\hline Si-NPS & $64.43 \pm 10.50 \mathrm{~nm}$ & ICR mice & $\begin{array}{l}20 \text { mg/kg b.w., } 15 \text { d, intrave- } \\
\text { nous injection }\end{array}$ & $\begin{array}{l}\text { Induced hepatic damage, } \\
\text { fibrosis, and TGF- } \beta 1 / \text { SMAD3 } \\
\text { signaling activation }\end{array}$ & {$[6]$} \\
\hline $\mathrm{TiO}_{2}-\mathrm{NPS}$ & $21 \mathrm{~nm}$ & Rats & $\begin{array}{l}0.5,1.5,5,15,50 \text {, and } 150 \mathrm{mg} / \\
\text { kg b.w.; intratracheal instilla- } \\
\text { tion, } 1 \text { month }\end{array}$ & $\begin{array}{l}\text { Induced hepatic profibrotic } \\
\text { alterations }\end{array}$ & {$[57]$} \\
\hline $\mathrm{TiO}_{2}-\mathrm{NPS}$ & $5-6 \mathrm{~nm}$ & ICR mice & $\begin{array}{l}\text { 2.5, 5, and } 10 \mathrm{mg} / \mathrm{kg} \text { b.w.; oral } \\
\text { administration, } 9 \text { months }\end{array}$ & $\begin{array}{l}\text { Triggered hepatic fibrosis and } \\
\text { upregulated expression of } \\
\text { TGF-B/SMAD/MAPKWNTT } \\
\text { pathway-related factors }\end{array}$ & [58] \\
\hline Cu-NPs & $32.7 \pm 10.45 \mathrm{~nm}$ & SD rats & $\begin{array}{l}\text { 100, } 200 \text {, or } 400 \text { mg/kg b.w./ } \\
\text { day; } 28 \text { d, oral administra- } \\
\text { tion, }\end{array}$ & $\begin{array}{l}\text { Induced early hepatic fibrotic } \\
\text { changes via TGF- } \beta / S M A D \\
\text { signaling }\end{array}$ & {$[60]$} \\
\hline Ag-NPs & $56 \mathrm{~nm}$ & SD rats & $\begin{array}{l}30,125,500 \mathrm{mg} / \mathrm{kg} \text { b.w., oral } \\
\text { exposure, } 13 \mathrm{w}\end{array}$ & $\begin{array}{l}\text { Triggered fibrosis in the bile } \\
\text { duct }\end{array}$ & [63] \\
\hline $\mathrm{TiO}_{2}-\mathrm{NPS}$ & $6.5 \mathrm{~nm}$ & ICR mice & $\begin{array}{l}2.5,5,10 \mathrm{mg} / \mathrm{kg} \text { b.w.; nasal } \\
\text { exposure, } 9 \text { months }\end{array}$ & $\begin{array}{l}\text { Induced pulmonary toxicity } \\
\text { involving reactive free } \\
\text { radical-activated TGF- } \beta / \\
\text { SMAD/P38MAPK/WNT } \\
\text { signaling }\end{array}$ & {$[66]$} \\
\hline $\mathrm{NiO}-\mathrm{NPS}$ & $44 \mathrm{~nm}$ & Wistar rats, HepG2 cells & $\begin{array}{l}0.015-0.24 \mathrm{mg} / \mathrm{kg}, 9 \mathrm{w} \\
\text { intratracheal instillation }\end{array}$ & $\begin{array}{l}\text { Induced elevated levels of } \\
\text { types I and III collagen } \\
\text { in the liver and proteins } \\
\text { involved in TGF- } \beta \text { 1- } \\
\text { mediated SMAD pathway }\end{array}$ & [64] \\
\hline $\begin{array}{l}\text { MWCNTs, SWC- } \\
\text { NTs, Carbon } \\
\text { black }\end{array}$ & $\begin{array}{l}\text { CNTs: } 0.3-49 \mathrm{~nm} \times 0.5-10 \mu \mathrm{m}, \\
\text { Silica: } 1.6 \mu \mathrm{m} \text { Black carbon: } \\
14 \mathrm{~nm}\end{array}$ & J774A macrophages & $2.5 \mu \mathrm{g} / \mathrm{mL}, 24 \mathrm{~h}$ & $\begin{array}{l}\text { MWCNTS and SWCNTs stimu- } \\
\text { lated myofibroblast trans- } \\
\text { formation of macrophages }\end{array}$ & {$[201]$} \\
\hline
\end{tabular}

upregulation in immune cells and liver cells [73]. In vivo studies proved that Ni-NPs trigger miR-21 mediated pulmonary inflammation, fibrosis and protein expression changes (TGF- $\beta 1$ overexpression and SMAD2 phosphorylation) [75]. Further studies showed that miR-21 activation is involved in Ni-NP-induced MMP-2 and MMP-9 production $[72,91]$. Thus, we postulate that NMs may induce EMT and liver cancer progression by activating miR-21 expression.

Further tumor development and malignant progression are driven by a dynamic extracellular microenvironment that is impacted by environmental stimuli, immune cell participation, and inflammatory signaling. NF- $\mathrm{kB}$ signaling plays an essential role in the inflammation-fibrosiscancer axis. As discussed above, numerous NMs (such as $\mathrm{ZnO}, \mathrm{TiO}_{2}$ and $\mathrm{SiO}_{2}-\mathrm{NPs}$ ) promote the release of proinflammatory chemokines and cytokines (such as TNF- $\alpha$, IL-1 $\beta$, IL18 and IL- 6 ) by activating the ROS-mediated NF-kB pathway [44-47]. Notably, IL-6 production has a mitogenic effect on hepatocytes and can promote HCC progression [92]. Furthermore, within the microenvironment inside a tumor, cancer cells experience different degrees of hypoxia [93]. As a known enhancer of tumor invasion and metastasis, activation of hypoxia-inducible-factor $1 \alpha$ (HIF-1 $\alpha)$ also induces KC activation and cytokine release to contribute to a pro-oncogenic microenvironment. Current studies have shown that NMs, such as $\mathrm{Ni}-$, $\mathrm{Co}-, \mathrm{TiO}_{2}-$, and $\mathrm{ZnO}-\mathrm{NPs}$, induced elevated HIF-1 $\alpha$ levels by inducing ROS generation [67, 94-96]. Therefore, we assume that NMs may contribute to cancer development by inducing ROS-mediated inflammation via activating $\mathrm{NF}-\mathrm{\kappa B}$ signaling and hypoxia via activating HIF- $1 \alpha$ signaling.

$\mathrm{TiO}_{2}$-NPs exposure induce mutations in rat livers [97]. Further studies showed that $\mathrm{NMs}-$ i.e., $\mathrm{TiO}_{2}-, \mathrm{SiO}_{2^{-}}$, AgNPs and CNTs-induce mutations by directly binding to DNA and causing altered DNA conformation [98-102] or inducing excess ROS generation, interaction with nuclear proteins, cytoskeleton damage, disturbance of cell cycle checkpoint functions, and release of toxic metal ions from the NM surface [39, 97, 103-105]. Mutant P53 promotes the proliferation and survival of cancer cells. Mutant P53 also induces cancer progression by activating MAPK, TGF- $\beta$ and HIF1- $\alpha$ signaling [106]. NMs (i.e., SiNPs and CNTs) induce cell cycle disruption and increase mitotic spindles [105, 107-109]. Furthermore, P53 inhibition was observed during malignant transformation induced by NMs (i.e., Si-NPs and CNTs). In addition to the evidence that exposure to NMs (such as Si-NPs and CNTs) induces activation of these signals (MAPK, 
TGF- $\beta$ and HIF1- $\alpha)[6,56,88,110]$, we speculate that P53 mutation may be involved in NM-induced liver cancer progression by activating MAPK, TGF- $\beta$ and HIF1- $\alpha$ signaling.

Even if NMs have carcinogenic potential, NM-induced carcinogenesis or tumorigenesis has been demonstrated in few studies. As discussed above, the major drawback of current toxicological studies on NMs is the limited exposure time.

A schematic diagram of the signaling pathways involved in NM-induced liver cancer is shown in Fig. 5. Representative studies revealing the potential contributions of NMs to liver cancer are summarized in Table 4.

\section{Metabolic disorders}

\section{Iron accumulation disorders}

The liver is the main site of iron storage and plays a dominant role in iron homeostasis regulation by secreting most proteins involved in iron metabolism, such as hepcidin and transferrin.

Iron homeostasis dysregulation can result from chronic liver diseases, such as hepatitis, NAFLD and hepatic cancer. Because NM exposure likely induces these hepatic diseases, they may induce iron homeostasis dysregulation. Hepcidin overexpression leads to degradation of the receptor ferroportin, resulting in a block in iron efflux and iron overload. Hepcidin secretion can be stimulated by inflammation through IL-6, IL22, STAT3 signaling activation and the ERK/ MAPK and BMP/SMAD pathways [111]. Hepcidin overexpression occurs during the progression of liver diseases, such as hepatitis, NASH and hepatic cancers. Exposure to NMs, such as $\mathrm{Si}-, \mathrm{NiO}_{-}, \mathrm{SiO}_{2^{-}}$, and $\mathrm{Cu}-$ NPs, induce liver injury by activating the ERK/MAPK, SMAD, IL-6, STAT3 signaling pathways [44, 60, 62, $64,85,112]$. Thus, NM exposure likely induces iron overload by stimulating hepcidin secretion and activating the ERK/MAPK, SMAD, IL-6, STAT3 signaling pathways.

Additionally, excessive exposure to iron oxide NPs (IONPs) directly leads to iron overload. IONP exposure-induced iron overload and liver toxicity have been reported [113]. The toxic mechanism of IONPs mainly results from ROS generation and iron ion release. In vitro models showed IONP exposure induces increased intracellular iron concentrations $[114,115]$. The transition of iron from $\mathrm{Fe}^{3+}$ to ferrous $\mathrm{Fe}^{2+}$ in endosomes can trigger the Fenton reaction $\left(\mathrm{Fe}^{3+}+\mathrm{O}_{2}=\mathrm{Fe}^{2+}+\mathrm{O}_{2}{ }^{-}\right)$, resulting in oxygen radical generation. After degradation in endosomes, $\mathrm{Fe}^{2+}$ is then released into an iron pool in the cytoplasm and excess iron is stored in ferritin. Correspondingly, studies showed that the degradation of IONPs in the endosome of KCs leads to increased secretion of ferritin and cytokine release $[116,117]$.

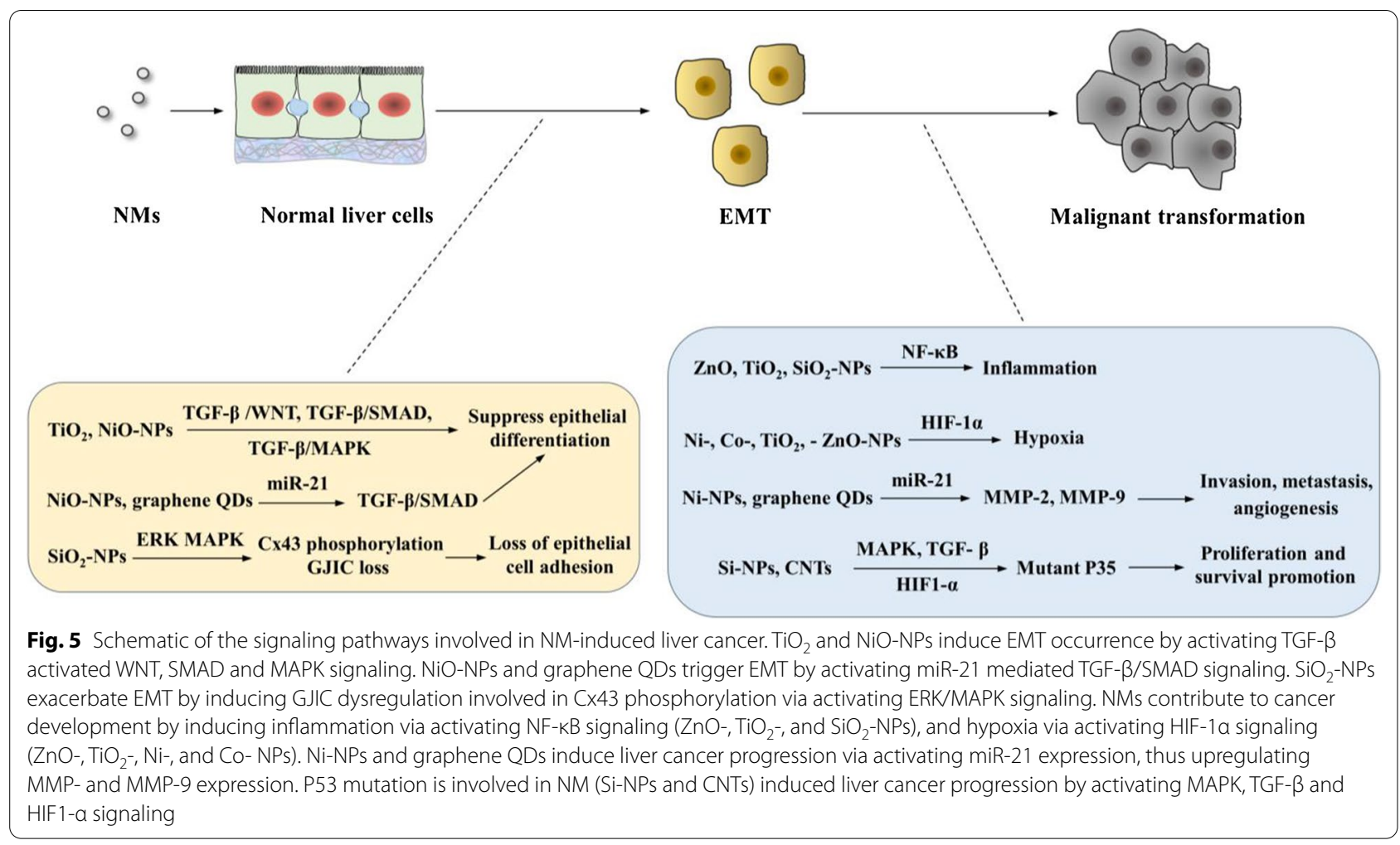




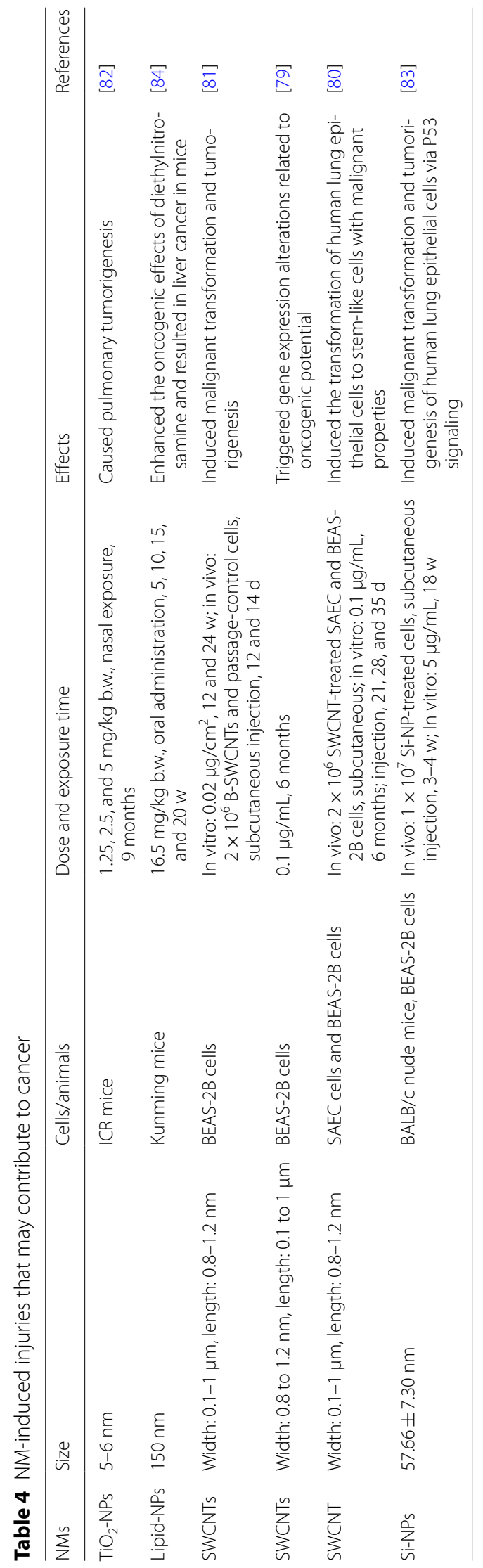


Finally, iron overload-induced excess ROS generation further induces ER stress, inflammation, and mitochondrial stress [118], resulting in an increased risk of hepatitis, NAFLD, fibrosis, cirrhosis and hepatic cancer.

\section{Copper accumulation disorders}

The liver is the main site of copper metabolism. High concentrations of copper NMs induce hepatic injuries, such as hepatic steatosis, inflammation, ROS generation, fibrosis and CYP450 depression $[37,119,120]$. $\mathrm{Cu}-\mathrm{NP}$ exposure leads to liver toxicity mainly because of the ability of $\mathrm{Cu}-\mathrm{NPs}$ to generate ROS, release copper ions and show high affinity for enzymes and proteins. Because copper is a highly soluble NM, the dissolution of copper ions contributes markedly to the toxicity of copper NPs. For example, in fetal calf serumfree DMEM, the solubility of copper ions released from $\mathrm{CuO}$-NPs was $66 \%$ [121]. In the presence of superoxide or reducing agents, $\mathrm{Cu}^{2+}$ is reduced to $\mathrm{Cu}^{+}$, which catalyzes the formation of hydroxyl radicals.

Current studies have revealed that $\mathrm{Cu}-\mathrm{NP}$ exposure leads to CYP450 inhibition in rats [36, 122, 123]. Because CYP450 enzymes are responsible for the metabolism of fatty acids and xenobiotics, their inhibition can reduce the hepatic biotransformation of NMs, aggravating the toxicity of NPs. Further studies showed that $\mathrm{Cu}^{2+}$ released from $\mathrm{Cu}-\mathrm{NPs}$ both oxidized and bound to some amino acid residues of the CYP450 monooxygenase, resulting in decreased CYP450 levels [124]. The hepatic CYP450 levels are activated by NF- $\mathrm{KB}$ [125] signaling and are closely related to MAPK [126] and STAT3 signaling [127]. Additionally, aryl hydrocarbon receptor (AHR), constitutive androstane receptor (CAR), and pregnane $X$ receptor (PXR) are regulators of CYP450s. More importantly, current studies have shown that $\mathrm{Cu}-\mathrm{NPs}$ induce CYP450 expression decrease via ROS-mediated activation of NF- $\mathrm{B}$, MAPK and STAT3 signaling pathways [36, 122, 128]. Additionally, elevated mRNA levels of PXR, CAR and AHR were detected in $\mathrm{Cu}-\mathrm{NP}$ treated rats [122]. Based on the above studies, we speculate that exposure to $\mathrm{Cu}$ NPs induces CYP450 depression, which aggravates the toxicity of NMs via ROS mediated activation of NF- $\kappa B$, MAPK and STAT3 signaling and overexpression of PXR, CAR and AHR.

Copper also participates in the synthesis of ceruloplasmin, promoting iron efflux in concert with ferroportin by oxidizing $\mathrm{Fe}^{2+}$ to $\mathrm{Fe}^{3+}$ [129]. Copper overaccumulation induces the depletion of ceruloplasmin. Thus, $\mathrm{Cu}-\mathrm{NP}$ exposure may induce decreased iron efflux and iron overload via depletion of ceruloplasmin. A schematic of NMinduced iron and copper toxicity is shown in Fig. 6.

\section{Toxicokinetics and toxicity of NMs in livers of susceptible individuals}

Subjects with liver disease

Studies have shown that the livers of subjects with liver disease, such as hepatitis or NASH, are more vulnerable than normal livers to exposure of NMs-i.e., Au-NRs, PEG-Au-NPs, and MWCNTs-because of the increased burden on liver cells [130-132]. The livers of subjects with liver disease are more vulnerable than normal livers likely because of increased NM accumulations in the liver.

Morphological and/or functional alterations in liver cells, as well as hepatic microcirculatory disorders, occur under hepatic pathological conditions, leading to altered NM distribution. For example, cancerous tissue and inflammatory reactions induce the release of proinflammatory cytokines and vascular endothelial growth factor (VEGF), resulting in increased LSEC fenestration-i.e., a loss of cellular integrity-triggering a gap between LSECs. This event allows NMs to extravasate from the blood system into the inflamed and cancerous tissue. By contrast, diseases such as liver fibrosis and cirrhosis are associated with decreased cellular distribution of NMs because the capillarization of LSECs causes the loss of LSEC fenestrae, appearance of a basement membrane, and increased ECM production, leading to decreased cellular distribution of NMs [69]. However, studies have proven that HSCs capture more NMs in fibrosis livers than in normal livers [133, 134]. The cause may be that, during fibrosis, HSCs proliferate 10-20 times and squeeze through LSEC fenestrations, leading to an increased chance of contact with blood. More importantly, during the progression of liver diseases, liver injuries-i.e., hepatocyte death and dysfunction-and increased energy consumption lead to decreased hepatic metabolism and clearance of NMs, which play a dominant role in facilitating disease progression. Therefore, the liver shows much higher plasma accumulation of various drugs in subjects with hepatitis, NASH, cirrhosis, cholestasis, and liver cancer than in normal subjects [135].

\section{Aging and young subjects}

Because of the senescence changes in aging subjects and immature physiological structures and functions in young subjects, they are more susceptible than adult individuals to injuries. Studies have proven the age-dependent deposition or translocation across physical barriers of NMs $[136,137]$. Additionally, in vivo and in vitro studies have shown that senile subjects and cells are more susceptible to NM exposure than young ones, followed by adult ones [138-140]. For example, Chen et al. [141] investigated $\mathrm{SiO}_{2}-\mathrm{NP}$ inhalation-induced toxic effects 


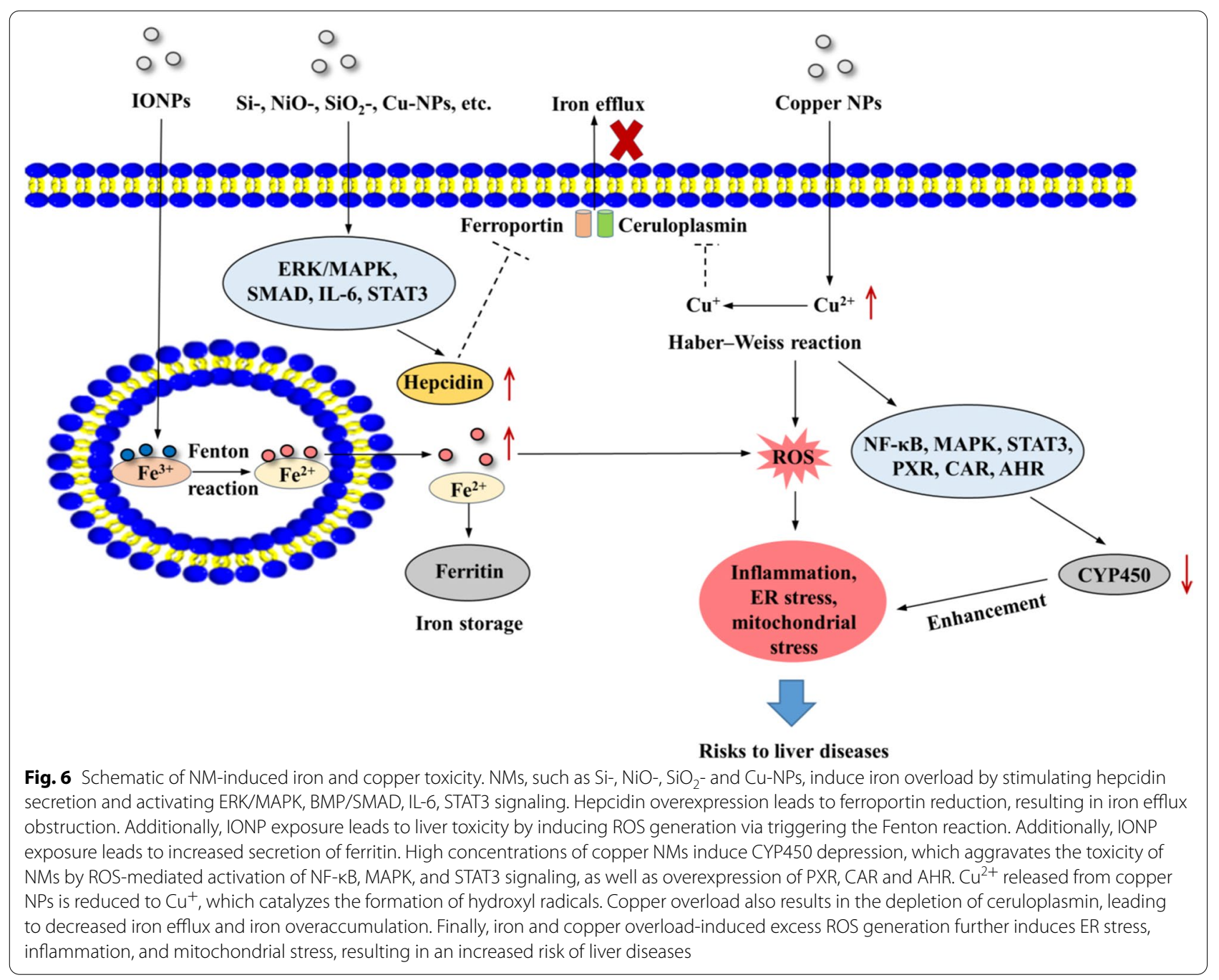

in rats and showed that the risk of pulmonary damage decreased in the order of old (20 months) $>$ young (3 $\mathrm{w})>$ adult $(8 \mathrm{w})$ rats and that a risk of cardiovascular disorder was observed only in older animals.

\section{Obese subjects}

Current studies have shown the livers of obese individuals are susceptible to NM exposure. Because the expansion of adipose tissue in obese subjects diminishes their ability to store excess energy, adipocyte dysfunction and enhanced lipolysis occur [131]. NM exposure further enhances obesity-driven lipolysis, resulting in increased levels of circulating FFAs and lipotoxicity, which enhance the development of hepatic diseases. For example, studies have revealed that NM exposure promotes obesitydriven liver diseases by inducing ROS generation, IR, proinflammatory activation of KCs and fatty acid oxidation [142, 143].

\section{Subjects of both sexes}

Male and female individuals differ in many aspects regarding the vulnerability to NMs and other stressors. Differences between sexes are attributed to sociocultural factors; exposure; genetic, molecular, and biochemical factors; body size and composition; and hormonal and reproductive factors. For example, after Ag-NP exposure, differentially expressed hepatic genes in male rats were involved in diabetes and metabolism, but metabolism and cell signaling changes were detected in female rats [144]. An in vitro study showed that female human amniotic stem cells captured more QDs than male cells, but male fibroblasts captured more QDs than female fibroblasts [145]. The differences in cell uptake could be attributed to variations in secreted paracrine factors and the cytoskeleton. More details on the role of sex in the toxicity of NMs or other xenobiotics are presented in other reviews $[146,147]$. 
Although NMs potentially trigger more severe toxic effects in susceptible livers, the current studies on NMinduced toxicity in susceptible liver models are still very limited. To reduce the gap between laboratory discoveries and safe application of NMs in various fields, overlooked factors that influence nanotoxicity must be examined. Hopefully, to better evaluate the safety of NMs in various fields, further studies will consider hepatic susceptibility-related factors.

\section{Factors affecting the toxicokinetics and toxicity of NMs}

The toxicokinetics and toxicity of NMs depend on the PCM characteristics of NMs (e.g., size, shape, charge, dissolution, agglomeration/aggregation, hydrophobicity/ hydrophilicity and functionalization) and interactions with biological systems.

\section{Concentration}

Various studies have proven that NM exposure causes dose-dependent liver toxicity in vivo and in vitro $[8,148$, 149]. Hepatocytes capture elevated NMs with increasing NM concentrations; however, when the concentration is exceeded by a certain amount, MPS uptake plays an important role because NMs at high concentrations are primarily uptake by MPS. For example, a PBPK model predicted that, with an increasing administration dose, the amount of Ag-NPs captured by the liver increased and was highest among organs in the highest dose group [150]. Furthermore, a PBPK model deduced that the MPS uptake rates were $0 \%, 25 \%$, and $100 \%$ of the original rate in the low-dose $(300 \mathrm{mg} / \mathrm{kg})$, moderate-dose $(500 \mathrm{mg} /$ $\mathrm{kg})$ and high-dose $(1000 \mathrm{mg} / \mathrm{kg})$ groups of intravenously administered Ag-NPs, respectively [150]. Kim et al. [151] proved that the uptake of Ag-NPs by the MPS is negligible below a blood Ag concentration of $180 \mathrm{ng} / \mathrm{g}$.

\section{Size}

The NM size plays a dominant role in their toxicokinetics and toxicity. Small NMs are more toxic than large NMs because of their higher reactive surface areas and ability to pass the biological barrier.

Large particles (submicron and micron scales) have a low likelihood of crossing the liver barrier because they show more efficient uptake by the MPS [5]. By contrast, small NMs can pass through the hepatic barrier more efficiently than large NMs because the diameter of LSEC fenestrae is reported to be 50 to $150 \mathrm{~nm}$ [152]. For example, an in vivo study confirmed that intravenously injected 18-nm Au-NPs were captured by KCs, LSECs and hepatocytes [28]. By contrast, after intravenous injection, 100- and 200-nm Au-NPs were observed only within the vessels of liver lobules [153]. Similarly, another in vivo study showed that $\mathrm{Ag}$ was present in $\mathrm{KCs}$, LSECs and hepatocytes in 10-nm-AgNP-treated mice; in portal endothelial cells, LSECs and KCs in 40-nm-AgNPtreated mice; and mostly in $\mathrm{KCs}$ in 100-nm-Ag-NPtreated mice [154]. Additionally, smaller NMs enter cells primarily through receptor-mediated or independent endocytosis, which occurs in all types of liver cells [155, $156]$. However, large NMs are mainly taken up by KCs via phagocytosis.

Small NMs pass through the ABB $[21,137,157]$ and GIT barrier [29] more efficiently than large NMs. For example, NMs with hydration diameters $<6 \mathrm{~nm}$ can pass through the ABB rapidly and enter lymph nodes and the bloodstream [158]. Furthermore, potential clearance from the body depends largely on the NM size. NMs larger than $100 \mathrm{~nm}$ are cleared only through the liver and MPS, but NMs with smaller sizes $(<6 \mathrm{~nm})$ can penetrate the renal tubules and enter the urine [4]. Larger NPs showed faster degradation than smaller NPs [159], likely because of their more efficient capture by the MPS.

Higher reactive surface areas of small NMs lead to higher toxicity. For example, the small $(10 \mathrm{~nm})$ Ag-NPs lead to higher silver tissue accumulation, resulting in overt acute toxic effects compared with the larger NPs (40 and $100 \mathrm{~nm}$ ) because small Ag-NPs present with higher silver iron dissolutions resulting from their higher reactive surface areas [154].

\section{Agglomeration/aggregation}

Agglomeration/aggregation affects NM uptake amounts and pathways. In vivo and in vitro studies have reported that agglomeration decreased the uptake of NMs (including $\mathrm{TiO}_{2^{-}}, \mathrm{Ni}-$, Si-, and Au-NPs) [155, 160-162], likely due to a reduced NM surface area. However, large agglomerates of NPs induce greater cellular uptake to macrophages than small agglomerates [163] because large agglomerates are more suitable than small agglomerates for phagocytosis [164].

Agglomeration/aggregation also substantially affects NM toxic behavior. Most studies have reported that agglomeration increases NM toxicity [155, 160-162], while other studies have revealed that agglomeration decreases NM toxicity [163, 165]. For example, oral gavage of large agglomerates of $\mathrm{TiO}_{2}$-NPs (primary size: $117 \mathrm{~nm}$ ) induces higher pulmonary responses in mice than oral gavage of small agglomerates [163]. However, Noël et al. [166] showed that inhaled exposure to large agglomerate aerosols of $\mathrm{TiO}_{2}-\mathrm{NPs}$ (primary size: 5-50 nm) does not induce more severe toxic effects than small agglomerate aerosols. Other factors (i.e., disperse/ culture medium, NM concentration, primary size of NMs, exposure time, exposure route and cell type) also affect the agglomeration profile and are responsible for 
the observed contradictory toxic effects of NM agglomeration. Interestingly, Noël et al. [166] proved that large agglomerate aerosols of $\mathrm{TiO}_{2}$-NPs induce an acute inflammatory response, while small agglomerate aerosols produce oxidative stress damage and cytotoxicity.

\section{Dissolution}

Dissolution, as a measure of biodurability, is dependent on the PCM properties (e.g., size and surface area) of $\mathrm{NMs}$ and suspension medium (e.g., $\mathrm{pH}$, ionic strength, and ion concentration). Biodurability has a potential influence on the toxicity of NMs.

According to current studies, the toxicity of highly soluble NMs mainly results from released iron, while that of poorly soluble NMs are mainly attributed to the NMs. For example, $\mathrm{Zn}^{2+}$ release largely contributes to $\mathrm{ZnO}$ NP-induced toxicity [167]; the CuO-NP-induced toxic effect originated from both the released irons and $\mathrm{CuO}$ $\mathrm{NPs}$; and the toxic effects of $\mathrm{ZrO}_{2^{-}}, \mathrm{Fe}_{2} \mathrm{O}_{3^{-}}, \mathrm{CeO}_{2^{-}}, \mathrm{Ag}-$ and NiO-NPs were mainly related to the metal NPs [136, 168-171].

Dissolution of NMs is an important clearance route for translocation [172]. Thus, highly soluble NMs (i.e., $\mathrm{ZnO}-\mathrm{NPs}$ ) show more rapid and efficient translocation than $\mathrm{NMs}$ with low solubility (e.g., $\mathrm{CeO}_{2^{-}}, \mathrm{TiO}_{2^{-}}$, and $\mathrm{Au}-$ NPs) because of the reduced dimensions of highly soluble NMs [136, 168, 173]. For example, in vivo data showed that an $\mathrm{SiO}_{2}$ coating attenuated the dissolution of $\mathrm{ZnO}$ NPs, decreasing their translocation rate across the ABB from $7.4 \%$ to $6.7 \%$ [174]. ZnO-NPs exhibit a much higher translocation rate across a lung epithelial cell monolayer than $\mathrm{CeO}_{2}$-NPs in vitro [173]. Additionally, biodurable NMs are more likely to be taken up and eliminated by the MPS. By contrast, non-biodurable NMs are captured and eliminated through the hepatic and renal pathways.

\section{Shape}

NMs come in various shapes-i.e., spherical, rod-like, needle-like, flake-like, fiber-like and horn-like. The shape of NMs determines their cellular uptake (endocytosis and phagocytosis), impacting their toxicity. Non-spherical NPs, particularly needle-shaped and rod-like analogous NMs, are more toxic because they more easily puncture the cell membrane to be subsequently taken up by cells [175]. Additionally, CNTs induce a greater hazard risk than other NMs mainly because of their fiber-like shape. The long fiber-like shape of CNTs leads to incomplete enclosure by macrophages, leading to frustrated phagocytosis and clearance. For example, a recent study showed that CNTs exhibit more toxicity over singlewalled carbon nanohorns by triggering more lysosome stress, protein expression changes, cell death, pyroptosis, necrosis and apoptosis in macrophages [5]. Additionally, the pulmonary fibrotic effects of CNTs are well established and even trigger a lung fibrotic response at a very early stage after exposure [176-178]. Furthermore, the carcinogenic potential, such as the level of centrosome fragmentation, mitotic spindle damage and aneuploidy after exposure to MWCNTs, is similar to the effects of the known carcinogen vanadium pentoxide [108].

\section{Hydrophobicity/hydrophilicity}

Hydrophobicity/hydrophilicity determines the NM biodistribution, cell uptake model, interaction between NMs and the cell membrane, and ability to pass the biological barrier.

For large NMs, membrane wrapping (i.e., endocytosis) has been recognized as the main cell uptake pathway, while small NMs with certain PCM properties tend to penetrate the cell membrane independently. Studies have demonstrated that the hydrophilic and hydrophobic NMs exhibit varied cell membrane interactions and cell uptake $[179,180]$. A computational model showed that hydrophobic NMs (10-40 nm) undergo penetration, leading to deformation and heterogeneity in the distribution of lipid molecules in the bilayer [181]. By contrast, hydrophilic NMs can be adsorbed on the surface of the bilayer rather than entering the core of the membrane, triggering membrane wrapping. In vitro studies further verify the results of computational models. Hydrophilic NMs-i.e., metal $\mathrm{NMs}$ - are generally taken up by cells via wrapping [155, 182, 183]. By contrast, hydrophobic NMs, such as fullerenes and graphene, undergo penetration into cells [181, 184].

Studies also proved the influence of hydrophobicity/ hydrophilicity on NM biodistribution and the ability to pass the biological membrane. For example, hydrophilic $\mathrm{TiO}_{2}$-NPs were freely distributed in the cytoplasm after contact with the buccal mucosa, whereas their hydrophobic counterparts were engulfed in the vesicular structures of the buccal mucosa [185]. Additionally, hydrophilic NMs exhibited priority to pass the blood-brain barrier and enter the cerebrospinal fluid [186].

\section{Charge}

The surface charge of NMs affects biological aspects such as biodistribution, cell uptake mode and plasma protein binding.

Positively charged NMs perturb the continuity of the plasma membrane and trigger more severe toxic effects than negatively charged NMs because of their interaction with the negatively charged surface of cells. For example, positively charged polystyrene NPs rather than negatively charged NPs induce apoptotic signaling to alveolar cells [187]. Studies have also proven that the surface charge determines the biodistribution of NPs, as well 
as the internalization and uptake mechanisms of cells. For example, Tang et al. [188] reported most of the negatively charged CdSe/ZnS core-shell QDs would deposit in the liver, but the positively charged QDs are detected in the lung. Nagy et al. [189] reported the positively charged CdS/ZnS-QDs were more likely to be phagocytosed by macrophages, and the negatively charged QDs were most likely to be incorporated. Surface charge also determines protein absorption, which affect corona formation. For example, an electrostatic model showed that, under neutral conditions, the local $\mathrm{pH}$ around positively and negatively charged NPs become very high and low, respectively, with a profound impact on the protein charge, hydration and affinity to the nanodiamonds [190]. Furthermore, surface charge affects the NM agglomeration/aggregation state through impacting the protein adsorption. For example, positively charged Au-NRs aggregate extensively when exposed to excised human skin compared with neutrally and negatively charged nanorods [191]. The aggregation of positively charged $\mathrm{Au}-\mathrm{NRs}$ is attributed to the adsorption of proteins released from skin.

\section{Functionalization}

Because NMs exhibit toxicity to living systems, surface modification of NMs is generally applied to reduce their toxicity effects and alter their toxicokinetics. Studies have confirmed that the functionalization of NMs such as polyethylene glycol (PEG), polyvinylpyrrolidone (PVP), and pluronic, largely decreases the toxicity and improves the biocompatibility of NMs. For example, PEG is mainly used for the passivation of NMs to obtain neutral surface charge, which prevents nonspecific protein absorption, immunological reaction and accumulation in the MPS [152]. Studies have shown that PEG-coated NPs induce fewer toxic effects than positive or negative NPs and reduce the sequestration of NPs by the MPS, thus increasing the circulation time [159, 188]. Lee et al. [192] reported that PEG-coated SWCNTs showed decreased adsorption of proteins, affecting corona formation and altering their toxicokinetics [193]. PVP-coated NMs also show altered distribution and decreased toxicity. For example, a recent study reported that PVP-coated $\mathrm{MoS}_{2}$ nanosheets show increased biodegradation and clearance [194]. Additionally, Wang et al. [195] reported PVP-coated Ag-NPs with the same particle size cause less DNA damage and chromosomal aberrations than uncoated NPs to hepatocytes.

\section{Corona}

After entering the internal environment, NMs are coated with coronas, such as those acquired in the serum, lung and GIT. Corona formation determines
NM toxicity because it affects the PCM properties of $\mathrm{NMs}$-i.e., aggregation/agglomeration, dissolution and hydrophilicity-which affect the cell uptake model and toxicokinetics of NMs. For example, the corona was reported to reduce the aggregation of $\mathrm{Au}-\mathrm{NPs}$ and $\mathrm{Au}-$ NRs, resulting in the processing of $15-\mathrm{nm}$ Au-NPs via the endocytosis pathway, a change in the processing of 45-nm Au-NPs by hepatocytes and gastric epithelial cells from receptor-mediated endocytosis to the macropinocytosis pathway, and a change in the processing of $\mathrm{Au}$ NRs $(33 \times 10 \mathrm{~nm})$ from receptor-mediated endocytosis to clathrin- and caveolin-independent pathways under non-fetal bovine serum-coated conditions [155]. Studies revealed corona formation also influences the dissolution and hydrophilicity of NMs, which affect the cell uptake of NMs [196, 197]. Additionally, corona formation can alter the recognition of NMs by the MPS because some components of the corona (i.e., albumin) lead to reduced phagocytosis [198], while other components (i.e., IgG and pulmonary surfactant proteins) result in increased phagocytosis [199].

\section{Conclusions and outlook}

The liver is the main organ targeted after exposure to NMs. Thus, the safety and effects of NMs in the liver are a research focus. This review highlights the possibility that NMs induce hepatic diseases, including NASH, fibrosis, liver cancer, and metabolic disorders, and explores the underlying intrinsic mechanisms based on the current understanding of NM toxicokinetics. Additionally, the toxicokinetics and potential risks of NMs in susceptible livers are summarized. The influences of the PCM properties of NMs on their toxicokinetics and toxicity are also explored. We hope to provide guidance for further toxicological studies on NMs that will be important to further develop NMs for applications in various fields.

Although some evidence of NM-induced liver diseases and intrinsic mechanisms is available, a wide gap between current knowledge and unexplored facts persists. The currently available studies have verified certain primary hepatotoxic effects of NMs; these toxic effects have not been linked to liver disease, and the toxicity mechanism remains unclear. Thus, in-depth studies on $\mathrm{NM}$-induced liver diseases and the intrinsic mechanisms with validation of effective methodologies and well-designed experimental models are needed. Additionally, most of the exposure times adopted in current studies represent acute, subacute and subchronic toxicity. Chronic hepatotoxicity studies of NMs are needed, particularly to observe NM-induced $\mathrm{NASH}$, liver fibrosis and cancer. Furthermore, NMs exhibit various distributions and exert enhanced toxic effects in susceptible livers, and this issue has been 
ignored in current toxicity studies. Therefore, further studies should consider susceptibility-related factors (including subjects with liver disease, obese individuals, aging and young individuals, and individuals of both sexes) to better evaluate the safety of NMs.

\begin{abstract}
Abbreviations
NMs: Nanomaterials; NPs: Nanoparticles; NASH: Nonalcoholic steatohepatitis; NAFLD: Nonalcoholic fatty liver disease; LSECs: Liver sinusoidal endothelial cells; KCs: Kupffer cells; HSCs: Hepatic stellate cells; BECs: Biliary epithelial cells; HPCs: Hepatic progenitor cells; MPS: Mononuclear phagocyte system; ECM: Extracellular matrix; ABB: Air-blood barrier; GIT: Gastrointestinal tract; PBPK: Physiologically based pharmacokinetics; PCM: Physicochemical and morphological; ILD: Initial lung dose; IPLD: Initial peripheral lung dose; BP: Black phosphorus; QDs: Quantum dots; NRs: Nanorods; CNTs: Carbon nanotubes; FFA: Free fatty acid; IR: Insulin resistance; IRS: Insulin receptors; PI3K: PI 3-kinase; STAT3: Signal transducer and activator of transcription 3; SMAD: Small mothers against decapentaplegic; TLRs: Toll-like receptors; ER: Endoplasmic reticulum; MMPs: Matrix metallopeptidases; MWCNTs: Multiwalled carbon nanotubes; SWCNT: Single-walled carbon nanotubes; SPIONs: Iron oxide nanoparticles; CYP450: Cytochrome P450; HCC: Hepatocellular carcinoma; EMT: Epithelial-to-mesenchymal transition; TGF- $\beta$ : Transforming growth factor B; AHR: Aryl hydrocarbon receptor; CAR: Constitutive androstane receptor; PXR: Pregnane X receptor; AHR: Aryl hydrocarbon receptor; CAR: Constitutive androstane receptor; PXR: Pregnane X receptor; PEG: Polyethylene glycol; PVP: Polyvinylpyrrolidone.
\end{abstract}

\section{Acknowledgements}

Not applicable.

\section{Authors' contributions}

All authors contributed to the design and concept of this article. TS drafted the manuscript, analyzed all the data and plotted all the figures. LS contributed to the review design. YK, JL and YZ critically revised the manuscript. LO, $\mathrm{XL}$ and $\mathrm{RL}$ collected the references. All the authors read and approved the final manuscript.

\section{Funding}

This work was supported by the Natural Science Foundation of Guangdong Province (2019A1515010263), Science and Technology Planning Project of Guangzhou (201904010059), Guangdong Medical Science and Technology Research Fund Project (A2018081) and Basic Research Operating Expenses of Central Universities of Jinan University (21620407).

\section{Availability of data and materials}

Databases/repositories and materials are not applicable in this review.

\section{Declarations}

Ethics approval and consent to participate

Not applicable.

\section{Consent for publication}

Not applicable.

\section{Competing interests}

The authors declare that they have no competing interests.

\section{Author details}

1 Foshan Stomatological Hospital, Foshan University, Foshan 528000, China.

${ }^{2}$ Stomatological Hospital, Southern Medical University, Guangzhou 510280, China. ${ }^{3}$ Medical Center of Stomatology, The First Affiliated Hospital, Guangzhou 510630, China.

Received: 27 August 2020 Accepted: 25 March 2021

Published online: 16 April 2021

\section{References}

1. Ameh T, Sayes CM. The potential exposure and hazards of copper nanoparticles: a review. Environ Toxicol Pharmacol. 2019;71:103220.

2. Wang J, Yu Y, Lu K, Yang M, Li Y, Zhou X, et al. Silica nanoparticles induce autophagy dysfunction via lysosomal impairment and inhibition of autophagosome degradation in hepatocytes. Int J Nanomedicine. 2017:12:809-25.

3. Winkler HC, Suter M, Naegeli H. Critical review of the safety assessment of nano-structured silica additives in food. J Nanobiotechnology. 2016;14(1):44

4. Zhang YN, Poon W, Tavares AJ, McGilvray ID, Chan WCW. Nanoparticleliver interactions: Cellular uptake and hepatobiliary elimination. J Control Release. 2016;240:332-48.

5. He B, Shi Y, Liang Y, Yang A, Fan Z, Yuan L, et al. Single-walled carbonnanohorns improve biocompatibility over nanotubes by triggering less protein-initiated pyroptosis and apoptosis in macrophages. Nat Commun. 2018;9(1):2393.

6. Yu Y, Duan J, Li Y, Li Y, Jing L, Yang M, et al. Silica nanoparticles induce liver fibrosis via TGF- $\beta(1) / S m a d 3$ pathway in ICR mice. Int J Nanomedicine. 2017;12:6045-57.

7. Zhang W, Zhao Y, Li F, Li L, Feng Y, Min L, et al. Zinc oxide nanoparticle caused plasma metabolomic perturbations correlate with hepatic steatosis. Front Pharmacol. 2018;9:57.

8. Chen R, Ling D, Zhao L, Wang S, Liu Y, Bai R, et al. Parallel comparative studies on mouse toxicity of oxide nanoparticle- and gadolinium-based T1 MRI contrast agents. ACS Nano. 2015;9(12):12425-35.

9. Lin $\mathrm{S}$, Wang $\mathrm{X}$, Ji Z, Chang $\mathrm{CH}$, Dong $\mathrm{Y}$, Meng $\mathrm{H}$, et al. Aspect ratio plays a role in the hazard potential of $\mathrm{CeO} 2$ nanoparticles in mouse lung and zebrafish gastrointestinal tract. ACS Nano. 2014:8(5):4450-64.

10. Pasquet J, Chevalier Y, Pelletier J, Couval E, Bouvier D, Bolzinger M-A. The contribution of zinc ions to the antimicrobial activity of zinc oxide. Colloids Surf, A. 2014;457:263-74.

11. Kwon JY, Koedrith P, Seo YR. Current investigations into the genotoxicity of zinc oxide and silica nanoparticles in mammalian models in vitro and in vivo: carcinogenic/genotoxic potential, relevant mechanisms and biomarkers, artifacts, and limitations. Int J Nanomedicine. 2014;9(Suppl 2):271-86.

12. Riebeling C, Haase A, Tralau T, Luch A. Substance classification of titanium dioxide illustrates limitations of EU legislation. Nature Food. 2020;1 (9):523-5.

13. ANSES. OPINION of the French Agency for Food, Environmental and Occupational Health \& Safety on the risks associated with ingestion of the food additive E171 [Internet]: Public Health; 2019. www.anses.fr/en/ system/files/ERCA2019SA0036EN.pdf.

14. Zain NM, Stapley AG, Shama G. Green synthesis of silver and copper nanoparticles using ascorbic acid and chitosan for antimicrobial applications. Carbohydr Polym. 2014;112:195-202.

15. Bobo D, Robinson KJ, Islam J, Thurecht KJ, Corrie SR. Nanoparticlebased medicines: a review of FDA-approved materials and clinical trials to date. Pharm Res. 2016;33(10):2373-87.

16. Elje E, Mariussen E, Moriones $\mathrm{OH}$, Bastús NG, Puntes $\mathrm{V}$, Kohl Y, et al. Hepato(Geno)toxicity assessment of nanoparticles in a HepG2 liver spheroid model. Nanomaterials (Basel). 2020;10(3):545.

17. Dong J, Ma Q. Advances in mechanisms and signaling pathways of carbon nanotube toxicity. Nanotoxicology. 2015;9(5):658-76.

18. Dussert F, Arthaud PA, Arnal ME, Dalzon B, Torres A, Douki T, et al. Toxicity to RAW264.7 macrophages of silica nanoparticles and the E551 food additive, in combination with genotoxic agents. Nanomaterials (Basel). 2020;10(7):1418.

19. Kreyling WG, Holzwarth U, Haberl N, Kozempel J, Hirn S, Wenk A, et al. Quantitative biokinetics of titanium dioxide nanoparticles after intravenous injection in rats: part 1. Nanotoxicology. 2017;11(4):434-42.

20. Kreyling WG, Holzwarth U, Haberl N, Kozempel J, Wenk A, Hirn S, et al. Quantitative biokinetics of titanium dioxide nanoparticles after intratracheal instillation in rats: part 3. Nanotoxicology. 2017;11(4):454-64.

21. Kreyling WG, Hirn S, Möller W, Schleh C, Wenk A, Celik G, et al. Air-blood barrier translocation of tracheally instilled gold nanoparticles inversely depends on particle size. ACS Nano. 2014;8(1):222-33.

22. Shinohara N, Oshima Y, Kobayashi T, Imatanaka N, Nakai M, Ichinose T, et al. Dose-dependent clearance kinetics of intratracheally 
administered titanium dioxide nanoparticles in rat lung. Toxicology. 2014:325:1-11.

23. Konduru NV, Molina RM, Swami A, Damiani F, Pyrgiotakis G, Lin P, et al. Protein corona: implications for nanoparticle interactions with pulmonary cells. Part Fibre Toxicol. 2017;14(1):42.

24. Balasubramanian SK, Poh KW, Ong CN, Kreyling WG, Ong WY, Yu LE. The effect of primary particle size on biodistribution of inhaled gold nanoagglomerates. Biomaterials. 2013;34(22):5439-52.

25. Geraets L, Oomen AG, Schroeter JD, Coleman VA, Cassee FR. Tissue distribution of inhaled micro- and nano-sized cerium oxide particles in rats: results from a 28-day exposure study. Toxicol Sci. 2012;127(2):463-73.

26. Kreyling WG, Holzwarth U, Schleh C, Hirn S, Wenk A, Schäffler M, et al. Quantitative biokinetics over a 28 day period of freshly generated, pristine, $20 \mathrm{~nm}$ titanium dioxide nanoparticle aerosols in healthy adult rats after a single two-hour inhalation exposure. Part Fibre Toxicol. 2019;16(1):29.

27. Bachler G, Losert S, Umehara Y, von Goetz N, Rodriguez-Lorenzo L, Petri-Fink A, et al. Translocation of gold nanoparticles across the lung epithelial tissue barrier: combining in vitro and in silico methods to substitute in vivo experiments. Part Fibre Toxicol. 2015;12:18.

28. Hirn S, Semmler-Behnke M, Schleh C, Wenk A, Lipka J, Schäffler M, et al. Particle size-dependent and surface charge-dependent biodistribution of gold nanoparticles after intravenous administration. Eur J Pharm Biopharm. 2011;77(3):407-16.

29. Schleh C, Semmler-Behnke M, Lipka J, Wenk A, Hirn S, Schäffler M, et al. Size and surface charge of gold nanoparticles determine absorption across intestinal barriers and accumulation in secondary target organs after oral administration. Nanotoxicology. 2012;6(1):36-46.

30. Kreyling WG, Holzwarth U, Schleh C, Kozempel J, Wenk A, Haberl N, et al. Quantitative biokinetics of titanium dioxide nanoparticles after oral application in rats: part 2. Nanotoxicology. 2017;11(4):443-53.

31. He B, Lin P, Jia Z, Du W, Qu W, Yuan L, et al. The transport mechanisms of polymer nanoparticles in Caco-2 epithelial cells. Biomaterials. 2013;34(25):6082-98.

32. Wildt BE, Celedon A, Maurer El, Casey BJ, Nagy AM, Hussain SM, et al. Intracellular accumulation and dissolution of silver nanoparticles in L-929 fibroblast cells using live cell time-lapse microscopy. Nanotoxicology. 2016;10(6):710-9.

33. Croissant JG, Fatieiev Y, Khashab NM. Degradability and Clearance of Silicon, Organosilica, Silsesquioxane, Silica Mixed Oxide, and Mesoporous Silica Nanoparticles. Adv Mater. 2017;29(9).

34. Yang B, Yin J, Chen Y, Pan S, Yao H, Gao Y, et al. 2D-Black-PhosphorusReinforced 3D-Printed Scaffolds:A Stepwise Countermeasure for Osteosarcoma. Adv Mater. 2018;30(10).

35. Friedman SL, Neuschwander-Tetri BA, Rinella M, Sanyal AJ. Mechanisms of NAFLD development and therapeutic strategies. Nat Med. 2018;24(7):908-22.

36. Tang $H, X u M$ M, Shi F, Ye G, Lv C, Luo J, et al. Effects and mechanism of nano-copper exposure on hepatic cytochrome P450 enzymes in rats. Int J Mol Sci. 2018;19(7):2140.

37. Chen Z, Meng H, Xing G, Chen C, Zhao Y, Jia G, et al. Acute toxicological effects of copper nanoparticles in vivo. Toxicol Lett. 2006;163(2):109-20.

38. Balasubramanian SK, Jittiwat J, Manikandan J, Ong CN, Yu LE, Ong WY. Biodistribution of gold nanoparticles and gene expression changes in the liver and spleen after intravenous administration in rats. Biomaterials. 2010;31(8):2034-42.

39. Kitchin KT, Stirdivant S, Robinette BL, Castellon BT, Liang X. Metabolomic effects of $\mathrm{CeO} 2, \mathrm{SiO} 2$ and $\mathrm{CuO}$ metal oxide nanomaterials on HepG2 cells. Part Fibre Toxicol. 2017;14(1):50.

40. Kitchin KT, Grulke E, Robinette BL, Castellon BT. Metabolomic effects in HepG2 cells exposed to four $\mathrm{TiO} 2$ and two $\mathrm{CeO} 2$ nanomaterials. Environ Sci Nano. 2014;1 (5):466-77.

41. Enea M, Araújo AM, Almeida MP, Soares ME, Gonçalves-Monteiro S, Pinho PG, et al. A metabolomic approach for the in vivo study of gold nanospheres and nanostars after a single-dose intravenous administration to wistar rats. Nanomaterials (Basel). 2019;9(11):1606.

42. Kumar M, Nath S, Prasad HK, Sharma G, Li YJP. MicroRNAs: a new ray of hope for diabetes mellitus. Protein Cell. 2012;3(10):726-38.
43. Du Q, Zhang S, Li A, Mohammad IS, Liu B, LiY. Astragaloside IV inhibits adipose lipolysis and reduces hepatic glucose production via Akt dependent PDE3B expression in HFD-fed mice. Front Physiol. 2018;9:15.

44. Hu H, Guo Q, Fan X, Wei X, Yang D, Zhang B, et al. Molecular mechanisms underlying zinc oxide nanoparticle induced insulin resistance in mice. Nanotoxicology. 2020;14(1):59-76.

45. Hu H, Guo Q, Wang C, Ma X, He H, Oh Y, et al. Titanium dioxide nanoparticles increase plasma glucose via reactive oxygen species-induced insulin resistance in mice. J Appl Toxicol. 2015;35(10):1122-32.

46. Hu H, Li L, Guo Q, Zong H, Yan Y, Yin Y, et al. RNA sequencing analysis shows that titanium dioxide nanoparticles induce endoplasmic reticulum stress, which has a central role in mediating plasma glucose in mice. Nanotoxicology. 2018;12(4):341-56.

47. Hu H, Fan X, Guo Q, Wei X, Yang D, Zhang B, et al. Silicon dioxide nanoparticles induce insulin resistance through endoplasmic reticulum stress and generation of reactive oxygen species. Part Fibre Toxicol. 2019;16(1):41.

48. Gurevitch D, Shuster-Meiseles T, Nov O, Zick Y, Rudich A, Rudich Y. $\mathrm{TiO} 2$ nanoparticles induce insulin resistance in liver-derived cells both directly and via macrophage activation. Nanotoxicology. 2012;6:804-12.

49. Mulens-Arias V, Rojas JM, Perez-Yague S, Morales MP, Barber DF. Polyethylenimine-coated SPIONs trigger macrophage activation through TLR-4 signaling and ROS production and modulate podosome dynamics. Biomaterials. 2015;52:494-506.

50. Dhupal M, Oh JM, Tripathy DR, Kim SK, Koh SB, Park KS. Immunotoxicity of titanium dioxide nanoparticles via simultaneous induction of apoptosis and multiple toll-like receptors signaling through ROSdependent SAPK/JNK and p38 MAPK activation. Int J Nanomedicine. 2018;13:6735-50.

51. Zhou H, Zhao K, Li W, Yang N, Liu Y, Chen C, et al. The interactions between pristine graphene and macrophages and the production of cytokines/chemokines via TLR- and NF-kappaB-related signaling pathways. Biomaterials. 2012;33(29):6933-42.

52. Wolf-Grosse S, Mollnes TE, Ali S, Stenvik J, Nilsen AM. Iron oxide nanoparticles enhance Toll-like receptor-induced cytokines in a particle sizeand actin-dependent manner in human blood. Nanomedicine (Lond). 2018;13(14):1773-85.

53. Yuan X, Nie W, He Z, Yang J, Shao B, Ma X, et al. Carbon black nanoparticles induce cell necrosis through lysosomal membrane permeabilization and cause subsequent inflammatory response. Theranostics. 2020;10(10):4589-605.

54. Gómez DM, Urcuqui-Inchima S, Hernandez JC. Silica nanoparticles induce NLRP3 inflammasome activation in human primary immune cells. Innate Immun. 2017;23(8):697-708.

55. Jia L, Vianna CR, Fukuda M, Berglund ED, Liu C, Tao C, et al. Hepatocyte Toll-like receptor 4 regulates obesity-induced inflammation and insulin resistance. Nat Commun. 2014;5:3878.

56. Kim JE, Lee S, Lee AY, Seo HW, Chae C, Cho MH. Intratracheal exposure to multi-walled carbon nanotubes induces a nonalcoholic steatohepatitis-like phenotype in C57BL/6J mice. Nanotoxicology. 2015;9(5):613-23.

57. Suker DK, Jasim FA. Liver histopathological alteration after repeated intra-tracheal instillation of titanium dioxide in male rats. Gastroenterol Hepatol Bed Bench. 2018;11(2):159-68.

58. Hong $F$, Ji J, Ze X, Zhou Y, Ze Y. Liver inflammation and fibrosis induced by long-term exposure to nano titanium dioxide $\left(\mathrm{TiO}_{2}\right)$ nanoparticles in mice and its molecular mechanism. J Biomed Nanotechnol. 2020;16(5):616-25.

59. Hong J, Zhang YQ. Murine liver damage caused by exposure to nanotitanium dioxide. Nanotechnology. 2016;27(11):112001.

60. Lee I-C, Ko J-W, Park S-H, Shin N-R, Shin I-S, Moon C, et al. Copper nanoparticles induce early fibrotic changes in the liver via TGF- $\beta / S$ mad signaling and cause immunosuppressive effects in rats. Nanotoxicology. 2018;12(6):637-51.

61. van der Zande M, Vandebriel RJ, Groot MJ, Kramer E, Herrera Rivera ZE, Rasmussen K, et al. Sub-chronic toxicity study in rats orally exposed to nanostructured silica. Part Fibre Toxicol. 2014;11(1):8.

62. Mahmoud AM, Desouky EM, Hozayen WG, Bin-Jumah M, El-Nahass ES, Soliman HA, et al. Mesoporous silica nanoparticles trigger liver and kidney injury and fibrosis via altering TLR4/NF-KB, JAK2/STAT3 and Nrf2/ HO-1 signaling in rats. Biomolecules. 2019;9(10):528. 
63. Kim YS, Song MY, Park JD, Song KS, Ryu HR, Chung YH, et al. Subchronic oral toxicity of silver nanoparticles. Part Fibre Toxicol. 2010;7:20.

64. Zhang Q, Chang X, Wang H, Liu Y, Wang X, Wu M, et al. TGF- $\beta 1$ mediated Smad signaling pathway and EMT in hepatic fibrosis induced by Nano $\mathrm{NiO}$ in vivo and in vitro. Environ Toxicol. 2020;35(4):419-29.

65. Zhang YE. Non-Smad signaling pathways of the TGF- $\beta$ family. Cold Spring Harb Perspect Biol. 2017;9(2):a022129.

66. Zhou Y, Ji J, Ji L, Wang L, Hong F. Respiratory exposure to nano-TiO(2) induces pulmonary toxicity in mice involving reactive free radicalactivated TGF- $\beta /$ Smad/p38MAPK/Wnt pathways. J Biomed Mater Res A. 2019;107(11):2567-75.

67. Huang KT, Wu CT, Huang KH, Lin WC, Chen CM, Guan SS, et al. Titanium nanoparticle inhalation induces renal fibrosis in mice via an oxidative stress upregulated transforming growth factor- $\beta$ pathway. Chem Res Toxicol. 2015;28(3):354-64.

68. Hong F, Zhou Y, Ye L, Ze Y, Ji J, Zhuang J, et al. Wnt pathway-mediated nano TiO(2)-induced toxic effects on rat primary cultured sertoli cells. J Biomed Nanotechnol. 2018;14(12):2124-34.

69. Tsuchida T, Friedman SL. Mechanisms of hepatic stellate cell activation. Nat Rev Gastroenterol Hepatol. 2017;14(7):397-411.

70. Liu X, Lu B, Fu J, Zhu X, Song E, Song Y. Amorphous silica nanoparticles induce inflammation via activation of NLRP3 inflammasome and HMGB1/TLR4/MYD88/NF-kb signaling pathway in HUVEC cells. J Hazard Mater. 2021:404(Pt B):124050.

71. Tao X, Wan X, Wu D, Song E, Song Y. A tandem activation of NLRP3 inflammasome induced by copper oxide nanoparticles and dissolved copper ion in J774A1 macrophage. J Hazard Mater. 2021:411:125134.

72. Mo Y, Zhang Y, Mo L, Wan R, Jiang M, Zhang Q. The role of miR-21 in nickel nanoparticle-induced MMP-2 and MMP-9 production in mouse primary monocytes: in vitro and in vivo studies. Environ Pollut. 2020;267:115597.

73. Hashemi MS, Gharbi S, Jafarinejad-Farsangi S, Ansari-Asl Z, Dezfuli AS. Secondary toxic effect of graphene oxide and graphene quantum dots alters the expression of miR-21 and miR-29a in human cell lines. Toxicol In Vitro. 2020;65:104796

74. Munsterman ID, Kendall TJ, Khelil N, Popa M, Lomme R, Drenth JPH, et al. Extracellular matrix components indicate remodelling activity in different fibrosis stages of human non-alcoholic fatty liver disease. Histopathology. 2018;73(4):612-21.

75. Mo Y, Zhang Y, Wan R, Jiang M, Xu Y, Zhang Q. miR-21 mediates nickel nanoparticle-induced pulmonary injury and fibrosis. Nanotoxicology. 2020;14(9):1175-97.

76. Dong J, Ma Q. Macrophage polarization and activation at the interface of multi-walled carbon nanotube-induced pulmonary inflammation and fibrosis. Nanotoxicology. 2018;12(2):153-68.

77. Rojas JM, Sanz-Ortega L, Mulens-Arias V, Gutiérrez L, Pérez-Yagüe S, Barber DF. Superparamagnetic iron oxide nanoparticle uptake alters M2 macrophage phenotype, iron metabolism, migration and invasion. Nanomedicine. 2016:12(4):1127-38.

78. Llovet JM, Zucman-Rossi J, Pikarsky E, Sangro B, Schwartz M, Sherman M, et al. Hepatocellular carcinoma. Nat Rev Dis Primers. 2016;2:16018.

79. Chen D, Stueckle TA, Luanpitpong S, Rojanasakul Y, Lu Y, Wang L. Gene expression profile of human lung epithelial cells chronically exposed to single-walled carbon nanotubes. Nanoscale Res Lett. 2015;10:12.

80. Luanpitpong S, Wang L, Castranova V, Rojanasakul Y. Induction of stemlike cells with malignant properties by chronic exposure of human lung epithelial cells to single-walled carbon nanotubes. Part Fibre Toxicol. 2014;11:22.

81. Wang L, Luanpitpong S, Castranova V, Tse W, Lu Y, Pongrakhananon V, et al. Carbon nanotubes induce malignant transformation and tumorigenesis of human lung epithelial cells. Nano Lett. 2011;11(7):2796-803.

82. Hong F, Ji L, Zhou Y, Wang L. Chronic nasal exposure to nanoparticulate $\mathrm{TiO}(2)$ causes pulmonary tumorigenesis in male mice. Environ Toxicol. 2017:32(5):1651-7.

83. Guo C, Wang J, Yang M, Li Y, Cui S, Zhou X, et al. Amorphous silica nanoparticles induce malignant transformation and tumorigenesis of human lung epithelial cells via P53 signaling. Nanotoxicology. 2017;11(9-10):1176-94

84. Zhang WK, Gu HW, Li XJ, Li YS, Tang HB, Tian GH, et al. The dark side of "the force"-lipid nanoparticles enhance the oncogenesis of diethylnitrosamine and result in liver cancer in mice. Nanomedicine. 2017;13(2):701-11.

85. Setyawati MI, Sevencan C, Bay BH, Xie J, Zhang Y, Demokritou P, et al. Nano-TiO(2) drives epithelial-mesenchymal transition in intestinal epithelial cancer cells. Small. 2018;14(30):e1800922.

86. Dudas J, Ladanyi A, Ingruber J, Steinbichler TB, Riechelmann H. Epithelial to mesenchymal transition: a mechanism that fuels cancer radio/ chemoresistance. Cells. 2020;9(2):428.

87. Mao XY, Li QQ, Gao YF, Zhou HH, Liu ZQ, Jin WL. Gap junction as an intercellular glue: emerging roles in cancer EMT and metastasis. Cancer Lett. 2016;381(1):133-7.

88. Lee GH, Kim YS, Kwon E, Yun JW, Kang BC. Toxicologic evaluation for amorphous silica nanoparticles: genotoxic and non-genotoxic tumorpromoting potential. Pharmaceutics. 2020;12(9):826.

89. Tsai CF, Cheng YK, Lu DY, Wang SL, Chang CN, Chang PC, et al. Inhibition of estrogen receptor reduces connexin 43 expression in breast cancers. Toxicol Appl Pharmacol. 2018;338:182-90.

90. Sadri Nahand J, Bokharaei-Salim F, Salmaninejad A, Nesaei A, Mohajeri F, Moshtzan A, et al. microRNAs: key players in virus-associated hepatocellular carcinoma. J Cell Physiol. 2019;234(8):12188-225.

91. Mo Y, Zhang Y, Wan R, Jiang M, Xu Y, Zhang Q. miR-21 mediates nickel nanoparticle-induced pulmonary injury and fibrosis. Nanotoxicology. 2020:1-23.

92. Kong L, Zhou Y, Bu H, LvT, Shi Y, Yang J. Deletion of interleukin- 6 in monocytes/macrophages suppresses the initiation of hepatocellular carcinoma in mice. J Exp Clin Cancer Res. 2016;35(1):131.

93. Quail DF, Joyce JA. Microenvironmental regulation of tumor progression and metastasis. Nat Med. 2013;19(11):1423-37.

94. Lin YF, Chiu IJ, Cheng FY, Lee YH, Wang YJ, Hsu YH, et al. The role of hypoxia-inducible factor-1a in zinc oxide nanoparticle-induced nephrotoxicity in vitro and in vivo. Part Fibre Toxicol. 2016;13(1):52.

95. Pietruska JR, Liu X, Smith A, McNeil K, Weston P, Zhitkovich A, et al. Bioavailability, intracellular mobilization of nickel, and HIF-1a activation in human lung epithelial cells exposed to metallic nickel and nickel oxide nanoparticles. Toxicol Sci. 2011;124(1):138-48.

96. Nyga A, Hart A, Tetley TD. Importance of the HIF pathway in cobalt nanoparticle-induced cytotoxicity and inflammation in human macrophages. Nanotoxicology. 2015;9(7):905-17.

97. El-Ghor AA, Noshy MM, Galal A, Mohamed HR. Normalization of nanosized TiO2-induced clastogenicity, genotoxicity and mutagenicity by chlorophyllin administration in mice brain, liver, and bone marrow cells. Toxicol Sci. 2014;142(1):21-32

98. Li N, Ma L, Wang J, Zheng L, Liu J, Duan Y, et al. Interaction between nano-anatase TiO 2 and liver DNA from mice in vivo. Nanoscale Res Lett. 2010;5(1):108-15.

99. Carriere M, Sauvaigo S, Douki T, Ravanat JL. Impact of nanoparticles on DNA repair processes: current knowledge and working hypotheses. Mutagenesis. 2017;32(1):203-13.

100. Chen M, von Mikecz A. Formation of nucleoplasmic protein aggregates impairs nuclear function in response to $\mathrm{SiO} 2$ nanoparticles. Exp Cell Res. 2005;305(1):51-62.

101. Rahban M, Divsalar A, Saboury AA, Golestani A. Nanotoxicity and spectroscopy studies of silver nanoparticle: calf thymus DNA and K562 as targets. J Physical Chem C. 2010;114(13):5798-803.

102. Li X, Peng Y, Ren J, Qu X. Carboxyl-modified single-walled carbon nanotubes selectively induce human telomeric i-motif formation. Proc Natl Acad Sci U S A. 2006;103(52):19658-63.

103. Huk A, Izak-Nau E, El Yamani N, Uggerud H, Vadset M, Zasonska B, et al. Impact of nanosilver on various DNA lesions and HPRT gene mutations-effects of charge and surface coating. Part Fibre Toxicol. 2015;12:25

104. Tee JK, Ong CN, Bay BH, Ho HK, Leong DT. Oxidative stress by inorganic nanoparticles. Wiley Interdiscip Rev Nanomed Nanobiotechnol. 2016:8(3):414-38

105. Siegrist KJ, Reynolds SH, Porter DW, Mercer RR, Bauer AK, Lowry D, et al. Mitsui-7, heat-treated, and nitrogen-doped multi-walled carbon nanotubes elicit genotoxicity in human lung epithelial cells. Part Fibre Toxicol. 2019;16(1):36.

106. Mantovani F, Collavin L, Del Sal G. Mutant p53 as a guardian of the cancer cell. Cell Death Differ. 2019;26(2):199-212. 
107. Sargent LM, Hubbs AF, Young SH, Kashon ML, Dinu CZ, Salisbury JL, et al. Single-walled carbon nanotube-induced mitotic disruption. Mutat Res. 2012;745(1-2):28-37.

108. Siegrist KJ, Reynolds SH, Kashon ML, Lowry DT, Dong C, Hubbs AF, et al. Genotoxicity of multi-walled carbon nanotubes at occupationally relevant doses. Part Fibre Toxicol. 2014;11:6.

109. Mascarenhas S, Mutnuri S, Ganguly A. Silica-a trace geogenic element with emerging nephrotoxic potential. Sci Total Environ. 2018;645:297-317.

110. Dashnyam K, Jin GZ, Kim JH, Perez R, Jang JH, Kim HW. Promoting angiogenesis with mesoporous microcarriers through a synergistic action of delivered silicon ion and VEGF. Biomaterials. 2017;116:145-57.

111. Brissot P, Loréal O. Iron metabolism and related genetic diseases: a cleared land, keeping mysteries. J Hepatol. 2016;64(2):505-15.

112. You R, Ho YS, Hung CH, Liu Y, Huang CX, Chan HN, et al. Silica nanoparticles induce neurodegeneration-like changes in behavior, neuropathology, and affect synapse through MAPK activation. Part Fibre Toxicol. 2018;15(1):28.

113. Wei Y, Zhao M, Yang F, Mao Y, Xie H, Zhou Q. Iron overload by superparamagnetic iron oxide nanoparticles is a high risk factor in cirrhosis by a systems toxicology assessment. Sci Rep. 2016;6:29110.

114. Paolini A, Guarch CP, Ramos-López D, de Lapuente J, Lascialfari A, Guari $Y$, et al. Rhamnose-coated superparamagnetic iron-oxide nanoparticles: an evaluation of their in vitro cytotoxicity, genotoxicity and carcinogenicity. J Appl Toxicol. 2016;36(4):510-20.

115. Mazuel F, Espinosa A, Luciani N, Reffay M, Le Borgne R, Motte L, et al. massive intracellular biodegradation of iron oxide nanoparticles evidenced magnetically at single-endosome and tissue levels. ACS Nano. 2016;10(8):7627-38

116. Kolosnjaj-Tabi J, Lartigue L, Javed Y, Luciani N, Pellegrino T, Wilhelm C, et al. Biotransformations of magnetic nanoparticles in the body. Nano Today. 2016;11(3):280-4.

117. Volatron J, Carn F, Kolosnjaj-Tabi J, Javed Y, Vuong QL, Gossuin Y, et al. Ferritin protein regulates the degradation of iron oxide nanoparticles. Small. 2017;13(2):1602030

118. Messner DJ, Rhieu BH, Kowdley KV. Iron overload causes oxidative stress and impaired insulin signaling in AML-12 hepatocytes. Dig Dis Sci. 2013;58(7):1899-908.

119. Liu H, Lai W, Liu X, Yang H, Fang Y, Tian L, et al. Exposure to copper oxide nanoparticles triggers oxidative stress and endoplasmic reticulum (ER)stress induced toxicology and apoptosis in male rat liver and BRL-3A cell. J Hazard Mater. 2021:401:123349.

120. Lee IC, Ko JW, Park SH, Shin NR, Shin IS, Moon C, et al. Comparative toxicity and biodistribution assessments in rats following subchronic oral exposure to copper nanoparticles and microparticles. Part Fibre Toxicol. 2016;13(1):56

121. Semisch A, Ohle J, Witt B, Hartwig A. Cytotoxicity and genotoxicity of nano- and microparticulate copper oxide: role of solubility and intracellular bioavailability. Part Fibre Toxicol. 2014;11:10.

122. Xu M, Tang H, Zhou X, Chen H, Dong Q, Zhang Y, et al. Effects and mechanisms of sub-chronic exposure to copper nanoparticles on renal cytochrome P450 enzymes in rats. Environ Toxicol Pharmacol. 2018:63:135-46.

123. Wang $Y$, Tang $H, X u M$, Luo J, Zhao L, Shi F, et al. Effect of copper nanoparticles on brain cytochrome P450 enzymes in rats. Mol Med Rep. 2019;20(1):771-8

124. Letelier ME, Faúndez M, Jara-Sandoval J, Molina-Berríos A, CortésTroncoso J, Aracena-Parks P, et al. Mechanisms underlying the inhibition of the cytochrome P450 system by copper ions. J Appl Toxicol. 2009:29(8):695-702

125. Zordoky BN, El-Kadi AO. Role of NF-kappaB in the regulation of cytochrome P450 enzymes. Curr Drug Metab. 2009;10(2):164-78.

126. Yang X, Deng S, Wei X, Yang J, Zhao Q, Yin C, et al. MAPK-directed activation of the whitefly transcription factor CREB leads to P450-mediated imidacloprid resistance. Proc Natl Acad Sci U S A. 2020;117(19):10246-53.

127. Yu L, Yang X, Ma B, Ying H, Shang $X$, He B, et al. Abnormal arachidonic acid metabolic network may reduce sperm motility via P38 MAPK. Open Biol. 2019;9(4):180091.
128. Manna P, Ghosh M, Ghosh J, Das J, Sil PC. Contribution of nano-copper particles to in vivo liver dysfunction and cellular damage: role of $\mathrm{kBa} /$ NF-KB. MAPKs Mitochondrial Signal Nanotoxicol. 2012;6(1):1-21.

129. Zheng J, Chen M, Liu G, Xu E, Chen H. Ablation of hephaestin and ceruloplasmin results in iron accumulation in adipocytes and type 2 diabetes. FEBS Lett. 2018;592(3):394-401.

130. Bartneck M, Ritz T, Keul HA, Wambach M, Bornemann J, Gbureck U, et al. Peptide-functionalized gold nanorods increase liver injury in hepatitis. ACS Nano. 2012:6(10):8767-77.

131. Hwang JH, Kim SJ, Kim YH, Noh JR, Gang GT, Chung BH, et al. Susceptibility to gold nanoparticle-induced hepatotoxicity is enhanced in a mouse model of nonalcoholic steatohepatitis. Toxicology. 2012:294(1):27-35.

132. Xu YY, Ge J, Zhang MH, Sun WJ, Zhang J, Yu PL, et al. Intravenous administration of multiwalled carbon nanotubes aggravates high-fat diet-induced nonalcoholic steatohepatitis in sprague dawley rats. Int J Toxicol. 2016;35(6):634-43.

133. Schwabe R, Bataller R. Liver fibrosis. Foreword. Semin Liver Dis. 2015;35(2):95-6.

134. Jiménez Calvente C, Sehgal A, Popov Y, Kim YO, Zevallos V, Sahin U, et al. Specific hepatic delivery of procollagen a $1(I)$ small interfering RNA in lipid-like nanoparticles resolves liver fibrosis. Hepatology. 2015;62(4):1285-97.

135. Almazroo OA, Miah MK, Venkataramanan R. Drug metabolism in the liver. Clin Liver Dis. 2017;21(1):1-20.

136. Kreyling WG, Möller W, Holzwarth U, Hirn S, Wenk A, Schleh C, et al. Age-dependent rat lung deposition patterns of inhaled 20 nanometer gold nanoparticles and their quantitative biokinetics in adult rats. ACS Nano. 2018;12(8):7771-90.

137. Tsuda A, Donaghey TC, Konduru NV, Pyrgiotakis G, Van Winkle LS, Zhang $Z$, et al. Age-dependent translocation of gold nanoparticles across the air-blood barrier. ACS Nano. 2019;13(9):10095-102.

138. Baratli Y, Charles AL, Wolff V, Ben Tahar L, Smiri L, Bouitbir J, et al. Age modulates $\mathrm{Fe} 3 \mathrm{O} 4$ nanoparticles liver toxicity: dose-dependent decrease in mitochondrial respiratory chain complexes activities and coupling in middle-aged as compared to young rats. Biomed Res Int. 2014;2014:474081.

139. Wang Y, Chen Z, Ba T, Pu J, Chen T, Song Y, et al. Susceptibility of young and adult rats to the oral toxicity of titanium dioxide nanoparticles. Small. 2013:9(9-10):1742-52.

140. Foroozandeh P, Aziz AA, Mahmoudi M. Effect of cell age on uptake and toxicity of nanoparticles: the overlooked factor at the nanobio interface. ACS Appl Mater Interfaces. 2019;11(43):39672-87.

141. Chen Z, Meng H, Xing G, Yuan H, Zhao F, Liu R, et al. Age-related differences in pulmonary and cardiovascular responses to $\mathrm{SiO} 2$ nanoparticle inhalation: nanotoxicity has susceptible population. Environ Sci Technol. 2008:42(23):8985-92.

142. Jia J, Li F, Zhou H, Bai Y, Liu S, Jiang Y, et al. Oral exposure to silver nanoparticles or silver ions may aggravate fatty liver disease in overweight mice. Environ Sci Technol. 2017;51(16):9334-43.

143. Yan YH, Chou CC, Lee CT, Liu JY, Cheng TJ. Enhanced insulin resistance in diet-induced obese rats exposed to fine particles by instillation. Inhal Toxicol. 2011;23(9):507-19.

144. Kim J, Sung J, Ks S, Ms D, Lee J, Nw S, et al. Toxicogenomic analysis for livers from Sprague-Daley rats following 12-week inhalation exposure to silver nanoparticles. J Nano Res. 2016;3(3):00058.

145. Serpooshan V, Sheibani S, Pushparaj P, Wojcik M, Jang AY, Santoso MR, et al. Effect of cell sex on uptake of nanoparticles: the overlooked factor at the nanobio interface. ACS Nano. 2018;12(3):2253-66.

146. Ray JL, Fletcher P, Burmeister R, Holian A. The role of sex in particleinduced inflammation and injury. Wiley Interdiscip Rev Nanomed Nanobiotechnol. 2020;12(2):e1589.

147. Gochfeld M. Sex differences in human and animal toxicology. Toxicol Pathol. 2017:45(1):172-89.

148. Sabella S, Carney RP, Brunetti V, Malvindi MA, Al-Juffali N, Vecchio G, et al. A general mechanism for intracellular toxicity of metal-containing nanoparticles. Nanoscale. 2014;6(12):7052-61.

149. Ou W, Mulik RS, Anwar A, McDonald JG, He X, Corbin IR. Low-density lipoprotein docosahexaenoic acid nanoparticles induce ferroptotic cell death in hepatocellular carcinoma. Free Radic Biol Med. 2017:112:597-607. 
150. Bachler G, von Goetz N, Hungerbühler K. A physiologically based pharmacokinetic model for ionic silver and silver nanoparticles. Int J Nanomedicine. 2013;8:3365-82.

151. Kim YS, Kim JS, Cho HS, Rha DS, Kim JM, Park JD, et al. Twenty-eightday oral toxicity, genotoxicity, and gender-related tissue distribution of silver nanoparticles in Sprague-Dawley rats. Inhal Toxicol. 2008;20(6):575-83.

152. Maslak E, Gregorius A, Chlopicki S. Liver sinusoidal endothelial cells (LSECS) function and NAFLD; NO-based therapy targeted to the liver. Pharmacol Rep. 2015;67(4):689-94.

153. Talamini L, Violatto MB, Cai Q, Monopoli MP, Kantner K, Krpetić Ž, et al. Influence of size and shape on the anatomical distribution of endotoxin-free gold nanoparticles. ACS Nano. 2017;11(6):5519-29.

154. Recordati C, De Maglie M, Bianchessi S, Argentiere S, Cella C, Mattiello S, et al. Tissue distribution and acute toxicity of silver after single intravenous administration in mice: nano-specific and size-dependent effects. Part Fibre Toxicol. 2016;13:12.

155. Ding L, Yao C, Yin X, Li C, Huang Y, Wu M, et al. Size, shape, and protein corona determine cellular uptake and removal mechanisms of gold nanoparticles. Small. 2018;14(42):e1801451.

156. Mortimer GM, Butcher NJ, Musumeci AW, Deng ZJ, Martin DJ, Minchin RF. Cryptic epitopes of albumin determine mononuclear phagocyte system clearance of nanomaterials. ACS Nano. 2014;8(4):3357-66.

157. Costa A, de Souza C-W, Seabra V, Sarmento B, Lehr CM. Triple co-culture of human alveolar epithelium, endothelium and macrophages for studying the interaction of nanocarriers with the air-blood barrier. Acta Biomater. 2019:91:235-47.

158. Choi HS, Ashitate Y, Lee JH, Kim SH, Matsui A, Insin N, et al. Rapid translocation of nanoparticles from the lung airspaces to the body. Nat Biotechnol. 2010;28(12):1300-3.

159. He Q, Zhang Z, Gao F, LiY, Shi J. In vivo biodistribution and urinary excretion of mesoporous silica nanoparticles: effects of particle size and PEGylation. Small. 2011;7(2):271-80.

160. Prasad RY, Wallace K, Daniel KM, Tennant AH, Zucker RM, Strickland J, et al. Effect of treatment media on the agglomeration of titanium dioxide nanoparticles: impact on genotoxicity, cellular interaction, and cell cycle. ACS Nano. 2013;7(3):1929-42.

161. Sager T, Wolfarth M, Keane M, Porter D, Castranova V, Holian A. Effects of nickel-oxide nanoparticle pre-exposure dispersion status on bioactivity in the mouse lung. Nanotoxicology. 2016;10(2):151-61.

162. Izak-Nau E, Voetz M, Eiden S, Duschl A, Puntes VF. Altered characteristics of silica nanoparticles in bovine and human serum: the importance of nanomaterial characterization prior to its toxicological evaluation. Part Fibre Toxicol. 2013;10(1):56.

163. Murugadoss S, Brassinne F, Sebaihi N, Petry J, Cokic SM, Van Landuyt KL, et al. Agglomeration of titanium dioxide nanoparticles increases toxicological responses in vitro and in vivo. Part Fibre Toxicol. 2020;17(1):10.

164. Kulkarni SA, Feng SS. Effects of particle size and surface modification on cellular uptake and biodistribution of polymeric nanoparticles for drug delivery. Pharm Res. 2013;30(10):2512-22.

165. Gualtieri M, Skuland T, Iversen TG, Låg M, Schwarze P, Bilaničová D, et al. Importance of agglomeration state and exposure conditions for uptake and pro-inflammatory responses to amorphous silica nanoparticles in bronchial epithelial cells. Nanotoxicology. 2012;6(7):700-12.

166. Noël A, Charbonneau M, Cloutier Y, Tardif R, Truchon G. Rat pulmonary responses to inhaled nano- $\mathrm{TiO}_{2}$ : effect of primary particle size and agglomeration state. Part Fibre Toxicol. 2013;10:48.

167. Król A, Pomastowski P, Rafińska K, Railean-Plugaru V, Buszewski B. Zinc oxide nanoparticles: synthesis, antiseptic activity and toxicity mechanism. Adv Colloid Interface Sci. 2017;249:37-52.

168. Kreyling WG, Holzwarth U, Hirn S, Schleh C, Wenk A, Schäffler M, et al. Quantitative biokinetics over a 28 day period of freshly generated, pristine, $20 \mathrm{~nm}$ silver nanoparticle aerosols in healthy adult rats after a single 11/2-hour inhalation exposure. Part Fibre Toxicol. 2020;17(1):21.

169. Wang D, Lin Z, Wang T, Yao Z, Qin M, Zheng S, et al. Where does the toxicity of metal oxide nanoparticles come from: The nanoparticles, the ions, or a combination of both? J Hazard Mater. 2016;308:328-34.

170. Xia T, Kovochich M, Liong M, Mädler L, Gilbert B, Shi H, et al. Comparison of the mechanism of toxicity of zinc oxide and cerium oxide nanoparticles based on dissolution and oxidative stress properties. ACS Nano. 2008;2(10):2121-34.
171. Sun T, Liu X, Zhan X, Ou L, Lai R. Hepatic distribution and toxicity of zirconia nanoparticles in vivo and in vitro. Process Saf Environ Prot. 2021;147:134-45.

172. Adamcakova-Dodd A, Stebounova LV, Kim JS, Vorrink SU, Ault AP, O'Shaughnessy PT, et al. Toxicity assessment of zinc oxide nanoparticles using sub-acute and sub-chronic murine inhalation models. Part Fibre Toxicol. 2014;11:15.

173. Cohen JM, Derk R, Wang L, Godleski J, Kobzik L, Brain J, et al. Tracking translocation of industrially relevant engineered nanomaterials (ENMs) across alveolar epithelial monolayers in vitro. Nanotoxicology. 2014;8(Suppl 1):216-25.

174. Konduru NV, Murdaugh KM, Sotiriou GA, Donaghey TC, Demokritou P, Brain JD, et al. Bioavailability, distribution and clearance of tracheally-instilled and gavaged uncoated or silica-coated zinc oxide nanoparticles. Part Fibre Toxicol. 2014;11:44.

175. Liu J, Kang Y, Yin S, Chen A, Wu J, Liang H, et al. Key role of microtubule and its acetylation in a zinc oxide nanoparticle-mediated lysosome-autophagy system. Small. 2019;15(25):e1901073.

176. Dong J, Ma Q. Integration of inflammation, fibrosis, and cancer induced by carbon nanotubes. Nanotoxicology. 2019;13(9):1244-74.

177. Sharma M, Nikota J, Halappanavar S, Castranova V, Rothen-Rutishauser B, Clippinger AJ. Predicting pulmonary fibrosis in humans after exposure to multi-walled carbon nanotubes (MWCNTs). Arch Toxicol. 2016;90(7):1605-22.

178. Labib S, Williams A, Yauk CL, Nikota JK, Wallin H, Vogel U, et al. Nanorisk science: application of toxicogenomics in an adverse outcome pathway framework for risk assessment of multi-walled carbon nanotubes. Part Fibre Toxicol. 2016;13:15.

179. Lin J, Miao L, Zhong G, Lin CH, Dargazangy R, Alexander-Katz A Understanding the synergistic effect of physicochemical properties of nanoparticles and their cellular entry pathways. Commun Biol. 2020;3(1):205.

180. Wang S, Guo H, Li Y, Li X. Penetration of nanoparticles across a lipid bilayer: effects of particle stiffness and surface hydrophobicity. Nanoscale. 2019:11(9):4025-34.

181. Curtis EM, Bahrami AH, Weikl TR, Hall CK. Modeling nanoparticle wrapping or translocation in bilayer membranes. Nanoscale. 2015:7(34):14505-14

182. Liu J, Kang Y, Yin S, Chen A, Wu J, Liang H, et al. Key role of microtubule and its acetylation in a zinc oxide nanoparticle-mediated lysosome-autophagy system. Small. 2020;16(18):e2001857.

183. Porter GC, Duncan WJ, Jude A, Abdelmoneim D, Easingwood RA, Coates DE. Endocytosed silver nanoparticles degrade in lysosomes to form secondary nanoparticle structures during expression of autophagy genes in osteogenic cells. Nanomedicine. 2021:33:102355.

184. Franskevych D, Palyvoda K, Petukhov D, Prylutska S, Grynyuk I, Schuetze $C$, et al. Fullerene $C(60)$ penetration into leukemic cells and its photoinduced cytotoxic effects. Nanoscale Res Lett. 2017;12(1):40.

185. Teubl BJ, Schimpel C, Leitinger G, Bauer B, Fröhlich E, Zimmer A, et al. Interactions between nano-TiO2 and the oral cavity: impact of nanomaterial surface hydrophilicity/hydrophobicity. J Hazard Mater. 2015;286:298-305.

186. Bourquin J, Milosevic A, Hauser D, Lehner R, Blank F, Petri-Fink A, et al. Biodistribution, clearance, and long-term fate of clinically relevant nanomaterials. Adv Mater. 2018;30(19):e1704307.

187. Ruenraroengsak P, Novak P, Berhanu D, Thorley AJ, Valsami-Jones E, Gorelik J, et al. Respiratory epithelial cytotoxicity and membrane damage (holes) caused by amine-modified nanoparticles. Nanotoxicology. 2012;6(1):94-108

188. Tang Y, Han S, Liu H, Chen X, Huang L, Li X, et al. The role of surface chemistry in determining in vivo biodistribution and toxicity of $\mathrm{CdSe} /$ ZnS core-shell quantum dots. Biomaterials. 2013;34(34):8741-55.

189. Nagy A, Zane A, Cole SL, Severance M, Dutta PK, Waldman WJ. Contrast of the biological activity of negatively and positively charged microwave synthesized CdSe/ZnS quantum dots. Chem Res Toxicol. 2011;24(12):2176-88.

190. Aramesh M, Shimoni O, Ostrikov K, Prawer S, Cervenka J. Surface charge effects in protein adsorption on nanodiamonds. Nanoscale. 2015;7(13):5726-36. 
191. Mahmoud NN, Al-Qaoud KM, Al-Bakri AG, Alkilany AM, Khalil EA. Colloidal stability of gold nanorod solution upon exposure to excised human skin: effect of surface chemistry and protein adsorption. Int J Biochem Cell Biol. 2016;75:223-31.

192. Lee H. Adsorption of plasma proteins onto PEGylated single-walled carbon nanotubes: the effects of protein shape, PEG size and grafting density. J Mol Graph Model. 2017;75:1-8.

193. Cao ZT, Gan LQ, Jiang W, Wang JL, Zhang HB, Zhang Y, et al. Protein binding affinity of polymeric nanoparticles as a direct indicator of their pharmacokinetics. ACS Nano. 2020;14(3):3563-75.

194. Mei L, Zhang X, Yin W, Dong X, Guo Z, Fu W, et al. Translocation, biotransformation-related degradation, and toxicity assessment of polyvinylpyrrolidone-modified 2H-phase nano-MoS(2). Nanoscale. 2019;11(11):4767-80.

195. Wang X, Li T, Su X, Li J, Li W, Gan J, et al. Genotoxic effects of silver nanoparticles with/without coating in human liver HepG2 cells and in mice. J Appl Toxicol. 2019;39(6):908-18.

196. Hu Q, Bai X, Hu G, Zuo YY. Unveiling the molecular structure of pulmonary surfactant corona on nanoparticles. ACS Nano. 2017;11(7):6832-42

197. Peng Q, Liu J, Zhang T, Zhang TX, Zhang CL, Mu H. Digestive enzyme corona formed in the gastrointestinal tract and its impact on epithelia cell uptake of nanoparticles. Biomacromol. 2019;20(4):1789-97.
198. Zhang T, Tang M, Yao Y, Ma Y, Pu Y. MWCNT interactions with protein: surface-induced changes in protein adsorption and the impact of protein corona on cellular uptake and cytotoxicity. Int J Nanomedicine. 2019;14:993-1009.

199. Gustafson HH, Holt-Casper D, Grainger DW, Ghandehari H. Nanoparticle uptake: the phagocyte problem. Nano Today. 2015;10(4):487-510.

200. Shinohara N, Danno N, Ichinose T, Sasaki T, Fukui H, Honda K, et al. Tissue distribution and clearance of intravenously administered titanium dioxide (TiO2) nanoparticles. Nanotoxicology. 2014;8(2):132-41.

201. Hindman B, Ma Q. Carbon nanotubes and crystalline silica stimulate robust ROS production, inflammasome activation, and IL-1 $\beta$ secretion in macrophages to induce myofibroblast transformation. Arch Toxicol. 2019;93(4):887-907.

202. Cargnoni A, Farigu S, Cotti Piccinelli E, Bonassi Signoroni P, Romele P, Vanosi G, et al. Effect of human amniotic epithelial cells on pro-fibrogenic resident hepatic cells in a rat model of liver fibrosis. J Cell Mol Med. 2018;22(2):1202-13.

\section{Publisher's Note}

Springer Nature remains neutral with regard to jurisdictional claims in published maps and institutional affiliations.
Ready to submit your research? Choose BMC and benefit from:

- fast, convenient online submission

- thorough peer review by experienced researchers in your field

- rapid publication on acceptance

- support for research data, including large and complex data types

- gold Open Access which fosters wider collaboration and increased citations

- maximum visibility for your research: over $100 \mathrm{M}$ website views per year

At BMC, research is always in progress.

Learn more biomedcentral.com/submissions 